\title{
History of Solar Car Technology and its Future Especially in Power Electronics
}

\author{
Hideki Jonokuchi*
}

Room 1018, Building No. 6, Nagoya Institute of Technology, Gokiso, Showa, Nagoya, 466-8555, Aichi Japan

\begin{abstract}
This paper describes the history and evolution of technologies related to the whole electrical system of solar car [1]. The components are the solar cell, maximum power point tracker, boost converter, motor\& Inverter and battery. In a solar car, it is difficult to arrange the solar cells on a flat vehicle surface, and solar cells with different incident angles and temperature is different in each cell. This is a problem when many solar cells with different characteristics are connected in series, and the improvement method will be described in detail. Next, we will explain the development of a boost converter using a GaN power device that can improve the overall running efficiency. We will also discuss the technological advances in motors \& inverters and batteries over the last 30 years. The evolution of solar cars is largely due to the evolution of semiconductors, including solar cells, and material technologies, but at the same time, we will explain examples of these technologies being first demonstrated in solar car race and then socially implemented.
\end{abstract}

Keywords: In-wheel motor, MPPT; Maximum Power Point Tracker, Concentrated/ Distributed MPPT, Step-down/ Boost converter, PWM inverter loss, Neodymium magnet, Power MOS FET, GaN power device, EV; Electric Vehicle, HEV; Hybrid Electric Vehicle, WSC; World Solar Challenge.

\section{INTRODUCTION}

A solar car can be defined as "a car that uses the energy obtained from the sun as power." Historically, attempts have been made to use Stirling engines and solar steam engines [2], but in reality, they can be thought of as "solar electric vehicles" [3]. Here, we will take a closer look at the history of solar cars. It cannot be overlooked that the invention and practical application of solar cells are related to the roots of semiconductor invention. The invention of the solar cell was made at Bell Telephone Labs [4] and was put to practical use by Eric Lidow, the founder of International Rectifire, who popularized Power MOSFETs around the world. Since then, solar cells have evolved significantly. Furthermore, the progress of semiconductors has been remarkable, leading to the practical application of MPPT [5, 6], and voltage booster for lower motor losses [7]. Advances in magnet materials and winding technology have made motors smaller, lighter, and more efficient. The advent of power semiconductors and new batteries has accelerated the practical application of EVs / HEVs. More than 30 years have passed since the first solar car race, but looking back, we can see that the solar car drive system has been always ahead of its time by incorporating the latest materials [8] and technologies

*Address correspondence to this author at the Room 1018, Building No. 6 , Nagoya Institute of Technology, Gokiso, Showa, Nagoya, 466-8555, Aichi Japan; Tel: +81-52-735-5436;

E-mail: h.jonokuchi.894@nitech.jp of the era. Here we will describe all the electrical system design for solar car with reviewing the history. In particular, as a technical finding, the output characteristics when a large number of solar cells with different characteristics are connected in series will be considered in detail.

\section{HISTORY OF SOLAR CAR}

The first solar car that actually run is "Solar King" by IRF; International Rectifier in 1958" shown in Figure 1. And Figure 2 is the specification of Solar King [9]. In 1981 Hans Tholstrup and Larry Perkins made a solar powered racecar; quiet achiever "Solar trek"shown in Figure 3 [10]. In 1982, the pair became the first to cross a continent in a solar car, from Perth to Sydney, Australia. Figure 4 shows the drive system of Solar Trek; Chain drive with DC motor. Hans Tholstrup became the creator of the World Solar Challenge competition. Following that, a lot of solar car races had been planned to raise public awareness.

At the first Australian World Solar Challenge in 1987, 23 participants were there, and followed by the Europe Tour Des Sol, the American Solar Chalenge, and Dream Cup Suzuka (Japan) [11]. Several huge companies and university vehicles excited these early races. The GM developed "Sunraycer" in 1987 for first WSC; world solar challenge. It could complete $3000 \mathrm{~km}$ trip with an average speed of $68 \mathrm{~km} / \mathrm{h}$. GM and Ford have developed their original solar car and got good position in WSC1987 [12]. In1993'," Honda dream" won [13].

(c) 2021 Zeal Press 


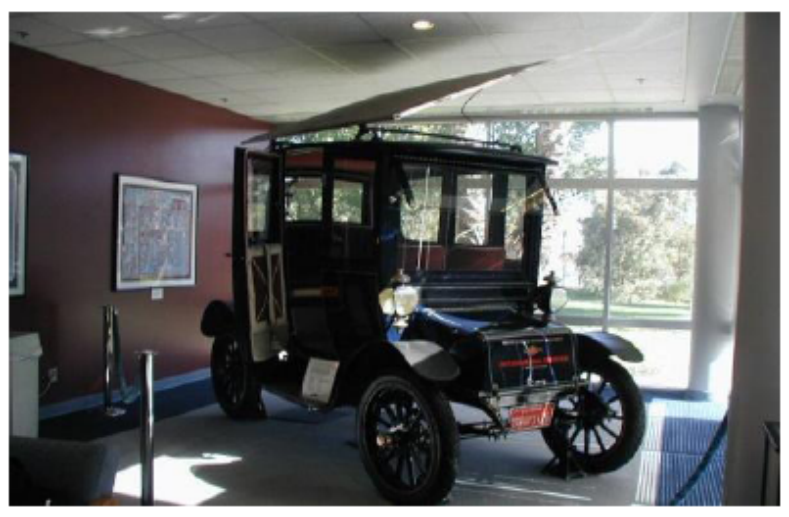

Figure 1: "Solar king" at IRF Temecula works.

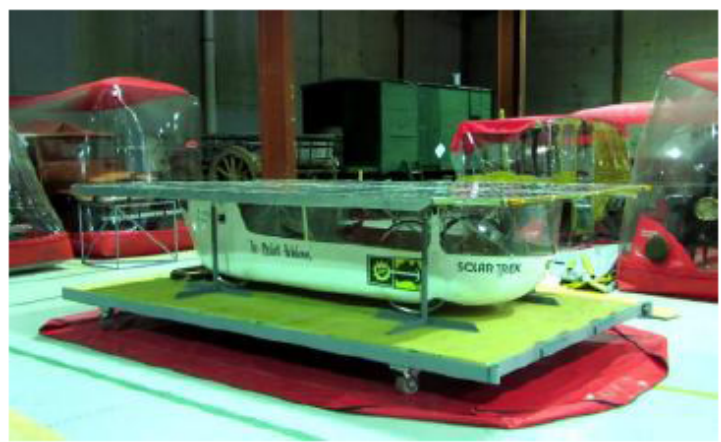

Figure 3: Quiet achiever; Solar Trek.

\section{SOLAR CAR DRIVE SYSTEM}

The solar car drive system was explained in "GM Sunraycer Case History [14]". Figure 5 shows the basic configuration of a solar car drive system. The electric energy generated by the solar cell is temporarily stored in the battery to drive the motor. In solar car racing, high efficiency (low loss) driving is the difference between victory and defeat. In that sense, the point is

(1) Conversion efficiency of solar cells,

(2) Technology to maximize it,

(3) High-efficiency motor\& Inverter.

In addition, the output power as a specification of the solar cell indicates that "it may be possible to output", and it is assumed that it is the value when it is used with the optimum impedance matching [15]. Therefore, you need an MPPT that has a hard ware to operate with low loss and a way to find the maximum power point (such as Hill-climbing). Next, as an example of high-efficiency drives including motors, replacing chain drives with direct drives (in-wheel

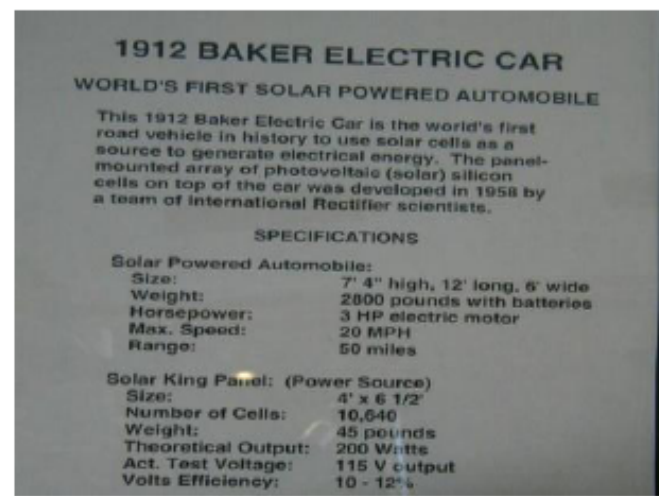

Figure 2: Spec of Solar King.

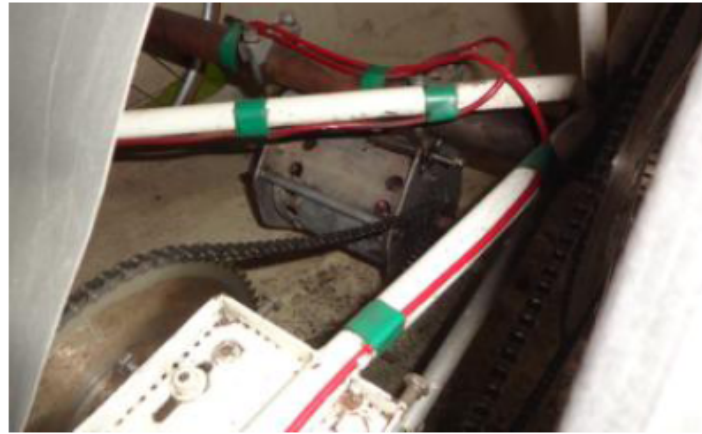

Figure 4: Chain drive with DC motor.

motors) [16] is also a major evolution. The in-whee motor can be realized with a brushless motor (BLM) [17] and is driven by an inverter. The battery acts as a power buffer that temporarily stores solar cell energy. A booster circuit has been developed to improve the operating efficiency of the system and installed between the battery and the motor inverter. Returning to solar car racing, these technological advances have made average cruising speeds exceed $90 \mathrm{~km} \mathrm{/} \mathrm{h,}$ making low aerodynamic design of the car body important.

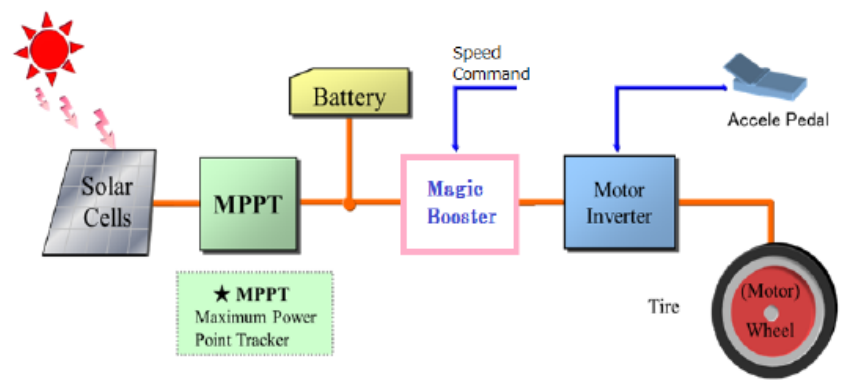

Figure 5: Solar car drive system. 


\section{ADVANCEMENT OF SOLAR CAR DRIVE UNITS}

\subsection{Solar Cells Advancement}

Silicon $\mathrm{p}-\mathrm{n}$ Junction Photocellis invented by D. M. Chapin, C. S. Fuller, and G. L. Pearson at Bell Laboratory [4]. In 1958, Eric Lidow, the founder of international Rectifire, started mass production of silicon solar cells. Solar cell historical milestone is shown in Table 1 [18].

Table 1: Solar Cell Historical Milestone in Early Day Break Period

\begin{tabular}{|c|l|c|}
\hline Date & \multicolumn{1}{|c|}{ Event } & AMO Eff \\
\hline \hline 1954 & Bell Labs invents solar cell(Silicon) & $-4 \%$ \\
\hline 1955 & Commercial products sold (radio) & \\
\hline 1956 & Sheet resistance decreased $\left(0.5 \times 2.0 \mathrm{~cm}^{2}\right.$ & $-8 \%$ \\
\hline 1958 & Application to Solar car & \\
\hline & Application to space (vanguard) & \\
\hline 1959 & Gridded front contact (printed) ranger & $-10 \%$ \\
\hline 1962 & Gridded front contact (photoresist) mariner & $-12 \%$ \\
\hline 1965 & N+/P cell improved radiation resistance & \\
\hline 1971 & Terrestrial market opened & \\
\hline 1975 & Textured front/P+ back field & $-15 \%$ \\
\hline 1983 & Large area/thin $\left(6 \times 7 \mathrm{~cm}^{2}, 62 \mathrm{um}\right)$ & $-18 \%$ \\
\hline 1987 & GaAs cell in production & \\
\hline
\end{tabular}

PV cell efficiency of "Solar King" was just 4.3\%. 30 years later, it was "GM Sunraycer" who won the WSC held in 1987. On the Sunraycer's photovoltaic solar cells covering an area of 90 sq. $\left(8.36 \mathrm{~m}^{2}\right)$. ft; combination of silicon (20\%) and gallium-arsenide $(80 \%)$ cells, producing up to $1400-1500$ Watts of power [19]. The Sunraycer's solar array was designed and built by experts from Hughes Aircraft and was the same type of gallium arsenide and silicon solar cells that Hughes used on their space satellites. The conversion efficiency of solar cells is estimated to be about $17 \%$ toatally. Gallium arsenide solar cells were used for the sunraycer that won the first tournament [20], but it was restricted from the second time onward because the arsenic contained in it was toxic.

In the second race of 1990, the Spirit of Beer / Bienne II of the Swiss School won the championship.

The 3rd race in 1993, and Honda's "Dream" won the championship for the first time with mono crystalline Si PV cells; $18 \%, 1,200 W$ [21, 22]. In 1999, the "local" Australian "Aurora" finally won the championship. Then, Nuna has won four consecutive titles from 2001 to 2007. Especially in 2005, he set a new record with an average speed of $102.75 \mathrm{~km} / \mathrm{h}$. This result led to a revision of the rules in 2007 in order to keep safety speed. The area of the solar panel was limited to $6 \mathrm{~m}^{2}$. Originally it was about $8 \mathrm{~m}^{2}$, so it decreased by $25 \%$. The Tokai Challenger of the Tokai University Solar Car Team won the 2009 tournament, and in 2005, like the Nuon Solar Team Nuna 3, cruised South Australia at $110 \mathrm{~km} / \mathrm{h}$, so the rules for reducing solar cells were reconsidered. As a result, the footprint of multijunction solar cells has been reduced from $6 \mathrm{~m}^{2}$ to $3 \mathrm{~m}^{2}$. On the other hand, since the silicon solar cell remains at $6 \mathrm{~m}^{2}$, it seems to become difficult to put multifunction cells solar cell into race practically. Figure $\mathbf{6}$ is the solar car from "NIT Horizon Z" with $6 \mathrm{~m}^{2}$ solar cells.

In 2017, with the same reason, the mounting area of the solar cell has been reduced from $6 \mathrm{~m}^{2}$ to $4 \mathrm{~m}^{2}$ silicon cell and $2.64 \mathrm{~m}^{2}$ composite multi-junction, and the body size has been reduced to $5 \mathrm{~m} \times 2.2 \mathrm{~m} \times 1.6 \mathrm{~m}$. "NIT Horizon Ace" meets the regulation@BWSC2019 shown in Figure 7. We adopted Sun power E60 Me3 cell for Horizon Ace in Figure 8.
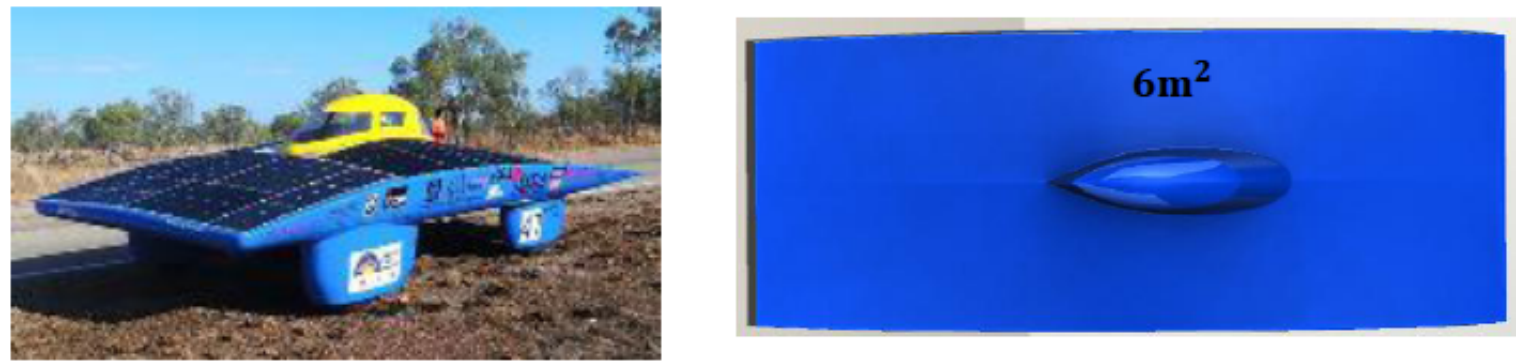

Figure 6: "NIT Horizon Z@BWSC2015” with 6m² solar cells. 

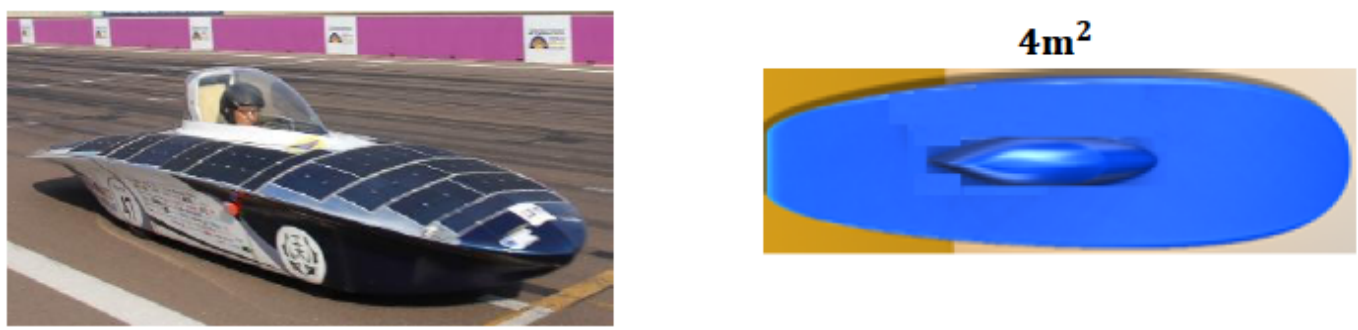

Figure 7: “NIT Horizon Ace@BWSC2019” with 4m² solar cells.

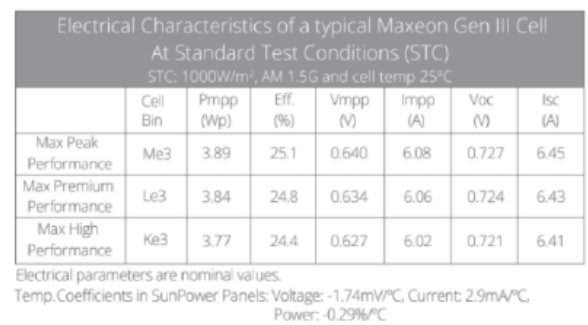

(a) E60 spec.

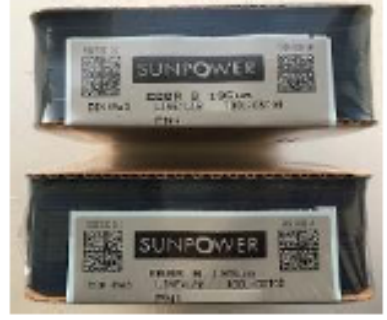

(b) Cell pack.

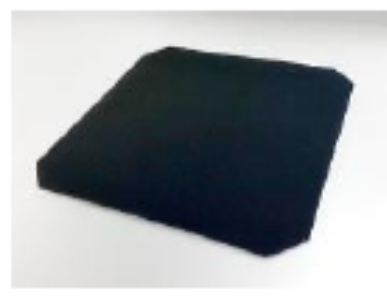

(c) Cell.

Figure 8: Solar cell of Horizon Ace.

Monocrystalline Silicon PV bear cells need to be capceled to protect them from moisture and dust. Encapsulation causes electrical loss and light loss. Especially in solar car racing, it is necessary to minimize the decrease in power conversion efficiency due to encapsulation. Figure 9 shows the change in conversion efficiency due to encapsulation. Encapsulation by "SunCat", but no degration is seen. Encapsulation has the function of preventing the reflection of sunlight and concentrating it, in addition to the function of the protective film of the silicon device, which is the point of ingenuity.

\subsection{Capturing More Photovoltaic Cell Power}

In a solar car, three measures are required to increase the output of the solar cell [23].

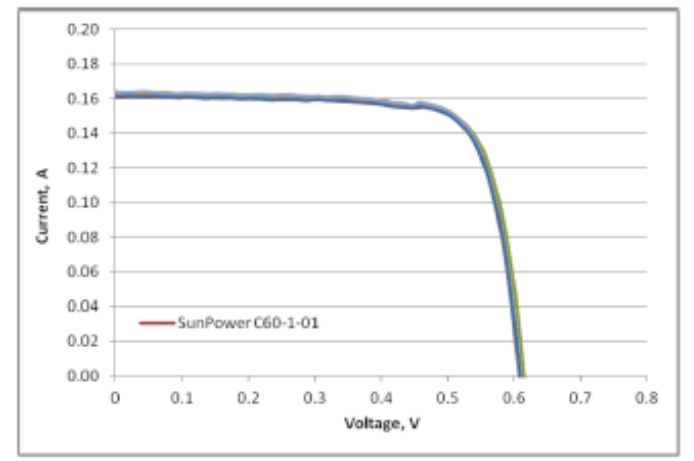

1. MPPT: the electrical impedance matching between the output impedance of the solar cell and the battery that receives the energy.

2. "Bypass diode" to minimize the effects of shadows.

3. Distributed MPPT: A device that finely controls the difference in the generated power of cells to obtain the maximum output as a whole. Also called "PV balancer".

\subsubsection{MPPT (Maximum Power Point Tracking)}

The importance of MPPT in solar power collection seems to date back to the first solar car racing world WSC87.

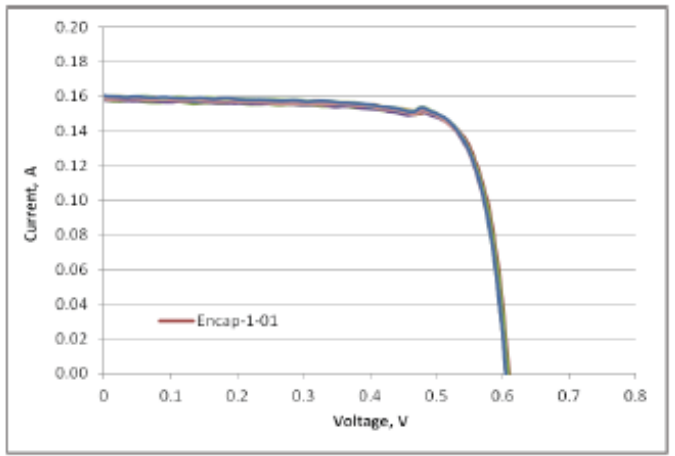

Figure 9: Changes in conversion efficiency due to encapsulation. 
MPPT functions as an impedance matching device. The load resistance;

z = V / I (z: impedance V: applied voltage I: load current). For example, if the current is halved, the apparent impedance doubles; refer to Figure 10.
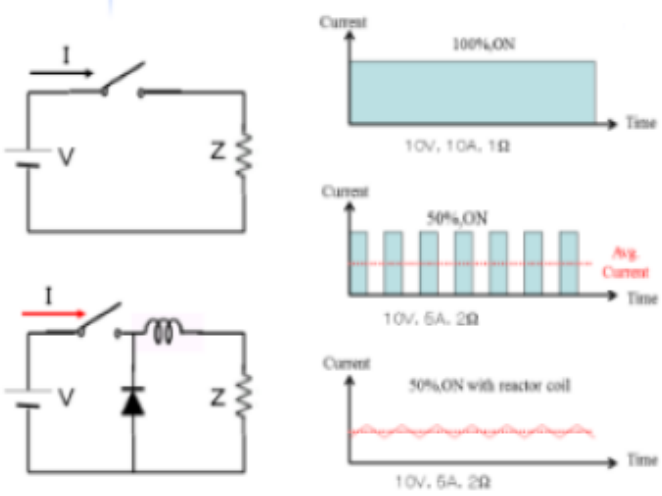

Figure 10: Impedance matching

The first MPPT for solar car in around 1987 had the performance of $96.6 \%$ efficiency with a $65 \mathrm{kHz}$ FET (Field Effect Transistor) converter using an open-loop algorithm while acquiring an open-circuit voltage sample of $3 \mathrm{~ms}$ every $2 \mathrm{sec}$ and establishing optimal operating parameters for GM Sunraycer. Battery charge maximum voltage is set to $140 \mathrm{~V}$, and solar panel's nominal output voltage is [set to $150 \mathrm{~V}$, and then it shows the Concentrated type MPPT with the stepdown converter. This MPPT has developed into EARL's "Maximizer." This was a commercial power tracker used by 6 out of the top ten cars in WSC1990.Since it was an open loop, it was necessary to set manually the maximum output point of the solar cell.

In 1992, Toshiba developed an all-digitally controlled MPPT that automatically searches for the maximum power point by applying the Hill climbing method (Figure 11) [24], with the step-up converter (Figure 12). The solar cell output voltage; MPPT input voltage, was about $100 \mathrm{~V}$, and Vehicle Battery voltage; MPPT output voltage was about $120 \mathrm{~V}$, then this MPPT is categorized to "Concentrated type MPPT. These MPPTs were installed in the solar car Esperanza developed by Kansai Electric Power Co., Inc., and they ran "solar car rally in Noto" held in 1992. And they are taken over by the Ashiya University team's solar cars Sky Ace TIGA, too [25]. Figure 13 is the concentrated MPPT.
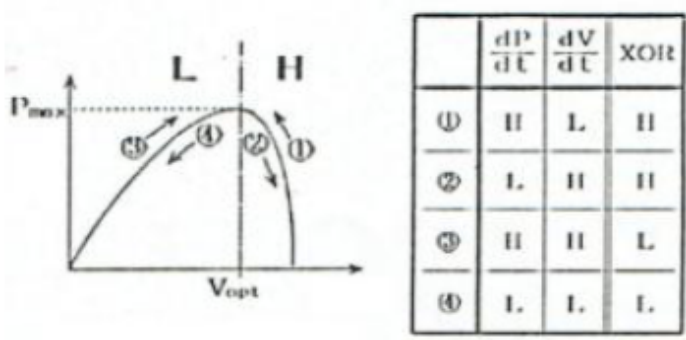

Figure 11: Hill climbing control method.

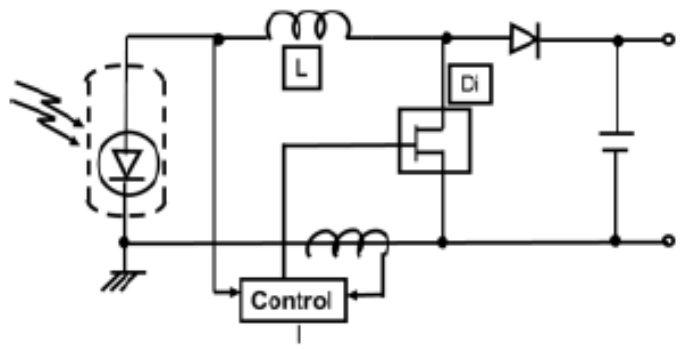

Figure 12: Step-up converter; Booster circuit.

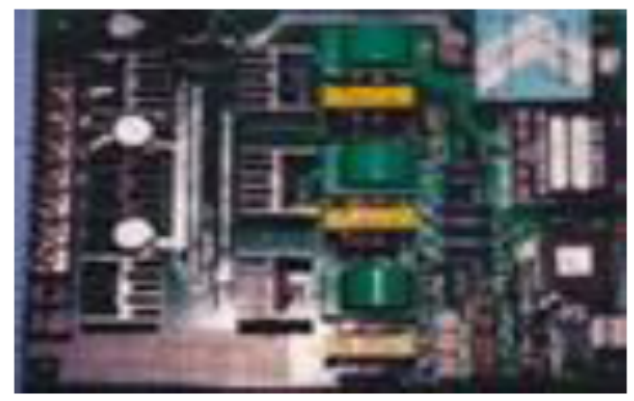

Figure 13: MPPT by Toshiba (Concentrated).

\subsubsection{Bypass Diode: to Minimize the Effects of Shadows}

Due to changes in BWSC regulations, area (See Figure 14). Since the canopy was placed on the left side, a big shadow was cast on the solar panel in the morning [26]. Figure 15 is upper view of Horizon 17. We insert a "bypass diode" to minimize the effects of shadows (See Figure 16).

Figure $\mathbf{1 7}$ is the simulation result of "with diode" or "without diode" with the case sunny $(100 \%$ output power) or dark ( $0 \%$ output power).

The simulation was performed using Matlab. standard model (solar cell, diode model, etc).

If one of the 26 cells is completely in shadow, the overall performance drops to $52 \%$ ( $48 \%$ loss) without the diode and $94 \%$ (just $6 \%$ loss) with the diode. 


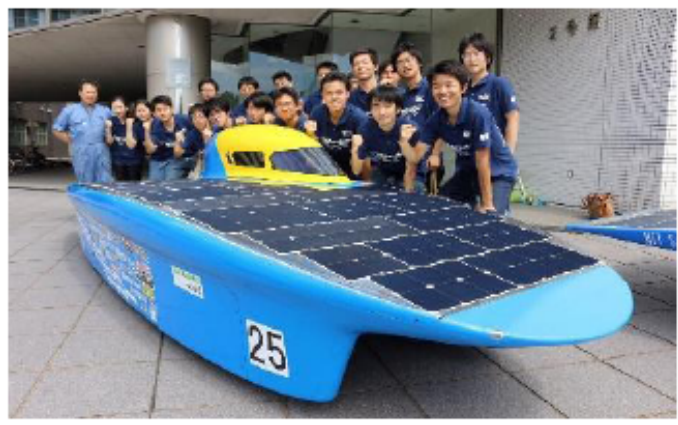

Figure 14: Catamaran shape of Horizon17.

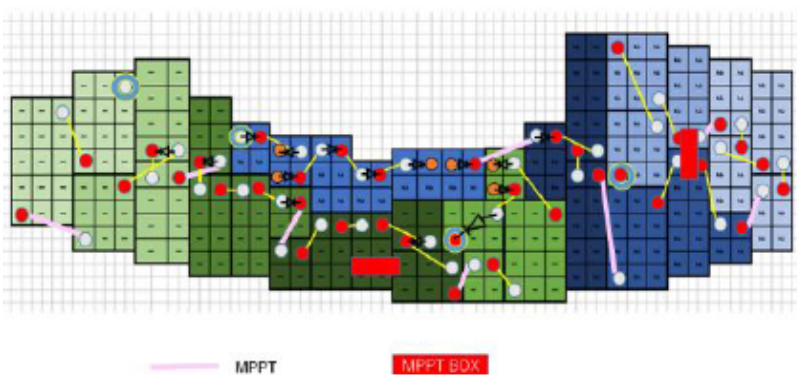

Figure 16: Bypass diode for shadow of canopy.

\subsubsection{Distributed MPPT for Various Cell Output Power}

Due to changes in BWSC regulations, the size of the car body will be reduced and the variation of solar cell mounting angle to the car body will be larger (See Figure 18). PV characteristics change depending on

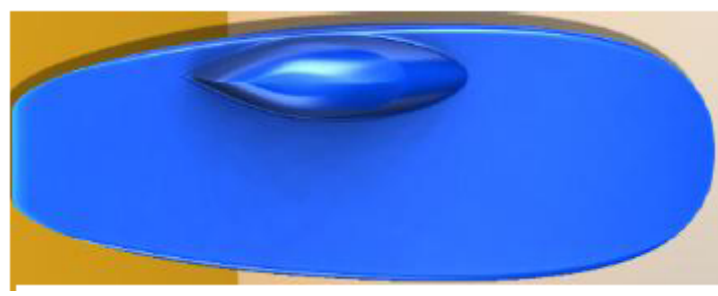

Figure 15: Upper view of Horizon 17.

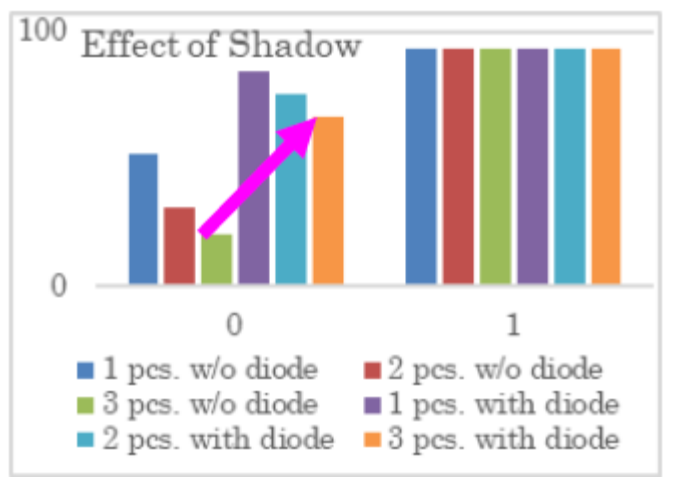

Figure 17: Bypass diode effect.

the amount of sun-light irradiation (angle of incidence). Figure 19 is the Cross section and Longitudinal section of Horizon Ace. It is considered that the number of cells connected in series to one MPPT input terminal will increase and the amount of each cell output voltage imbalance will increase a lot.
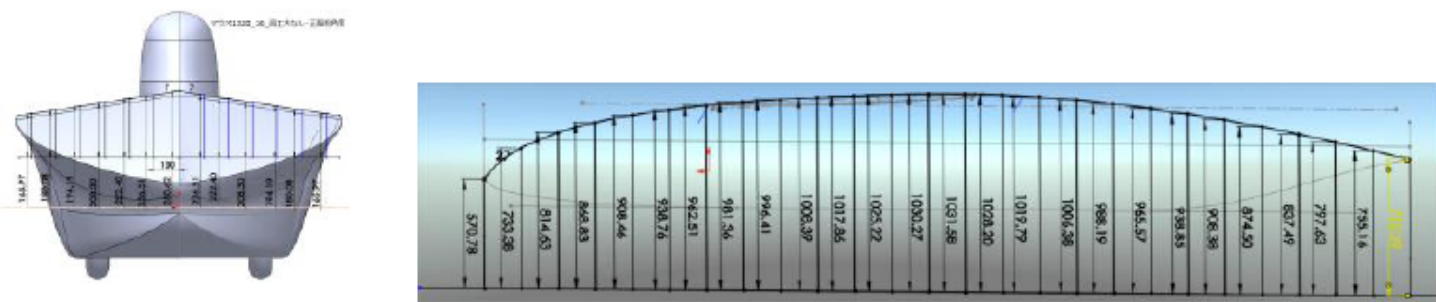

Figure 18: Cross section and Longitudinal section of Horizon Ace.
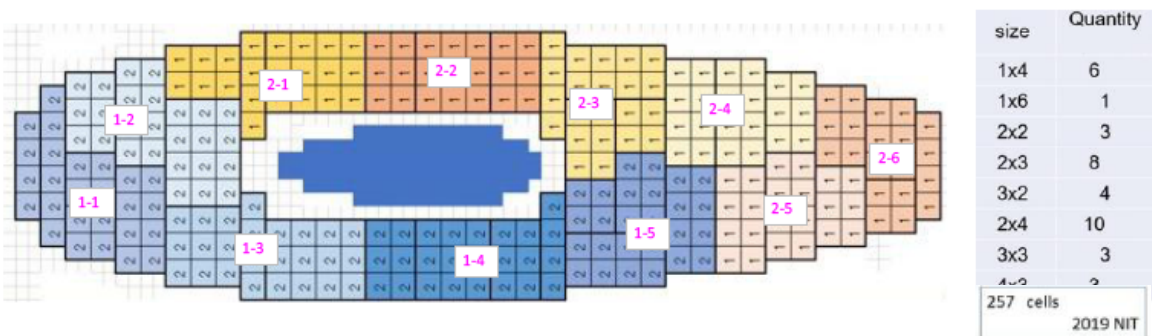

Figure 19: Horizon Ace panel layout and connection to MPPT. 
The solar cell area of Horizon Ace is $4 \mathrm{~m}^{2}$ and 267 solar cells are used. Cell module Group as is called string 1; composed of 5 modules (1-1 to 1-5), and Cell module Group 2 is called string 2; composed of 6 modules (2_1 to 2_6). A "curved (three-dimensional) structure" is used to reduce the air resistance of the vehicle body, and the difference in the amount of power generated by each solar cell tends to be large. Figure 20 is the simulation of each solar cell module output power with the following conditions.

*Location, Alice Springs

${ }^{*}$ Date and time, October 15, 2019

*Irradiation time, 12:30 around.

${ }^{*}$ Canopy shadow effect considered.

In string (1 and 2), each module is connected in series, and the overall solar cell output characteristics as a string are the characteristics that match the one with the lowest module output characteristics. In the case of String1, nearly $35 \%$ of the power down at (1-1) with concentrated MPPT. In string2, about 20\% down at (2-6) with concentrated MPPT. Distributed MPPT is being adopted to absorb and compensate for differences in power generation capacity between modules. This is thought to be mainly due to the introduction of ICs for MPPT controllers. SPV1020 (ST Micro electronics) was the best [27]. At that time, the 4phase interleaving method, the adoption of synchronous rectification with hill climbing algorithm, and the built-in power MOSFET were epoch-making (See Figure 21) [28]. Our team made some modifications such as increasing the thickness of the copper foil on the PCB plate.

\subsubsection{MPPT Performance with Synchronous Rectification}

Adopting distributed MPPT means increasing the number of MPPT units used, increasing the number of diodes used in the backflow prevention circuit of the booster circuit connected in series, and the loss due to the forward voltage $(\mathrm{Vf})$ of the diode cannot be ignored. Synchronous rectifier circuits have been introduced to reduce diode loss. Figure $\mathbf{2 2}$ shows the basic operation of the synchronous rectifier circuit. The wheeling current of the diode side can be reduced from $0.6 \mathrm{~V}$ to about $0.1 \mathrm{~V}$ by flowing back through the low resistance MOSFET on the high side. When using SunPower's $25 \%$ cell, the output current is about $6 \mathrm{~A}$, so the diode loss is $3.6 \mathrm{w}$ and the MOSFET reverse conduction loss is $0.6 \mathrm{w}$. The loss is expected to improve by $3 \mathrm{~W}$ per unit, totaling $33 \mathrm{~W}$ (11 units). In reality, not all will be improved due to the effects of dead time [29].

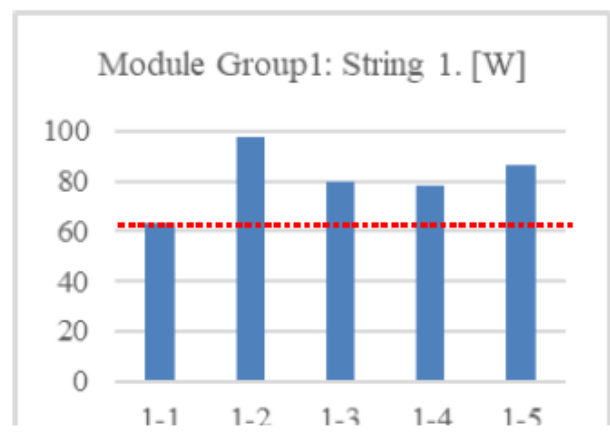

(a) Output of Cell module Group1.

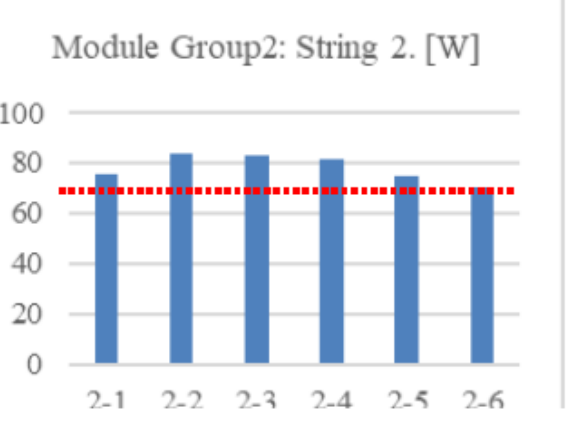

(b) Output of Cell module Group2.

Figure 20: Each solar cell module output power simulation.

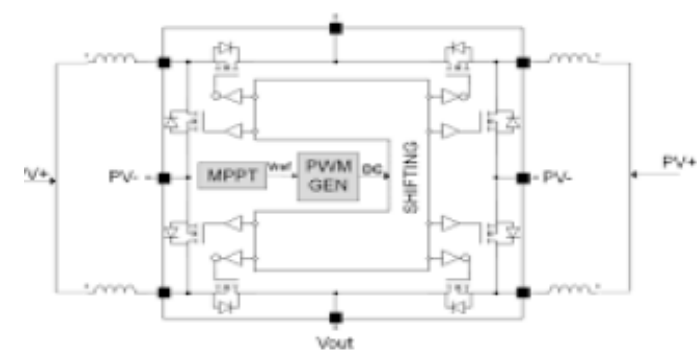

(a) Internal block diagram of SPV1020.

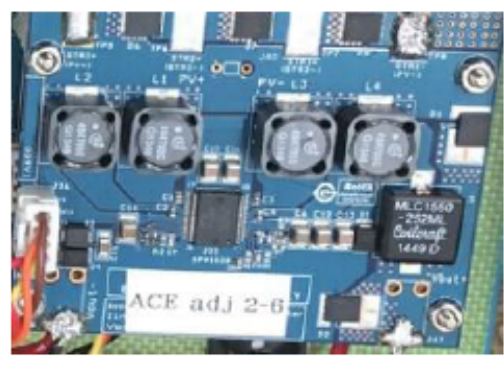

(b) MPPT with NIT modification.

Figure 21: Distributed MPPT using SPV1020 control IC. 


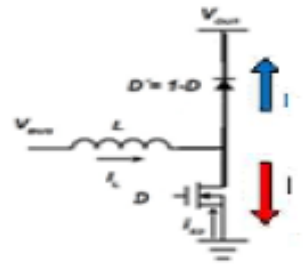

(a) Diode rectification.

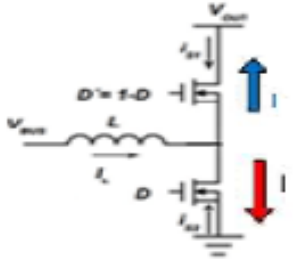

(b) Synchronous rectification.

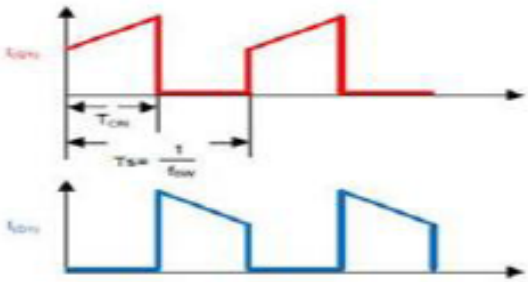

(c) Current flow.

Figure 22: Comparison of synchronous rectification and conventional diode.

\subsubsection{Optimal Number of Solar Cell Divisions and MPPT}

We explained that more solar energy can be collected by using distributed control, which installs multiple MPPTs per module unit instead of installing a centralized MPPT in the string unit. Further development of this idea leads to the story that each cell should have MPPT. However, it has been pointed out that if many cells with different power generation capacities are connected in series, the I-V characteristics of the solar cell module and string will not be monotonous. And it may not be possible to find the maximum output point due to the limits of the mountain climbing method. Figure 23 shows an image of the IV output characteristics of a solar cell module or module string connected in series when partially shaded.

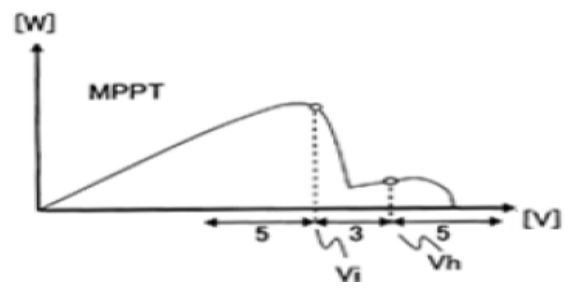

Figure 23: Image of I-V characteristics with big different cell in series connection.
As to Horizon Ace, a simulation have been performed to verify the possibility that the MPPT can not find out the Maximum Power Point with the strings by module in series connection, and with the module by cells in series connection. We have decided to consider the influence of shadows as the movement of the sun in the morning, day and evening, and as a point at Alice Springs, which is the midpoint of BWSC 2019. Figure $\mathbf{2 4}$ is the amount of solar power generated over time on each string. Figure $\mathbf{2 5}$ is the total output power: sum up of each module over time. The results show that the I-V output characteristics of all modules increase monotonically and decrease monotonically over time. As a result, the I-V characteristics of string 1 and string 2 have no inflection points, the maximum output point is set to 1 , and the maximum output point can be obtained by the mountain climbing method.

Figure $\mathbf{2 6}$ and Figure $\mathbf{2 7}$ show the power generation amount of the solar cell modules (1-1 to $1-5,2-1$ to $2-6)$ as the ratio of the power generation amount of each solar cell. "1.0" is a state in which sunlight is incident on the cell at a right angle. The difference in the amount of power generated by each cell is large for mod-ules $1-4$, which is about $7 \%$. In modules $1-5$ and $2-3$, fluctuations of about $6 \%$ can be seen. These fluctuations are a decrease in the power generation

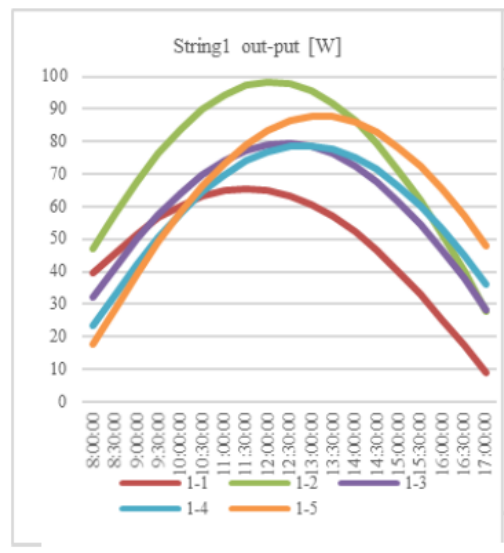

(a) String 1.

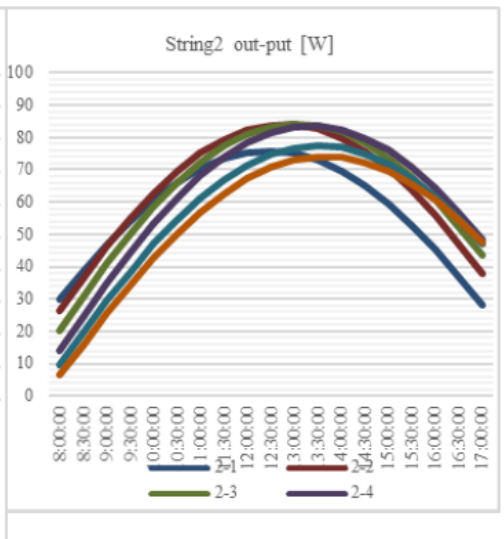

(b) String 2.

Figure 24: Changes in the amount of solar power generated over time on each string. 


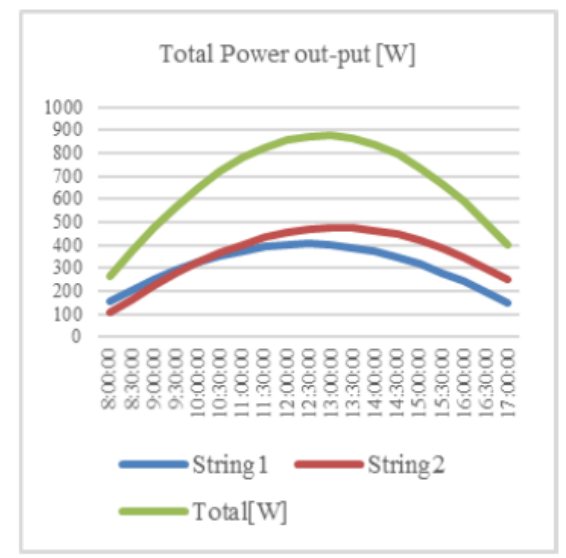

Figure 25: Total output power generated over time.

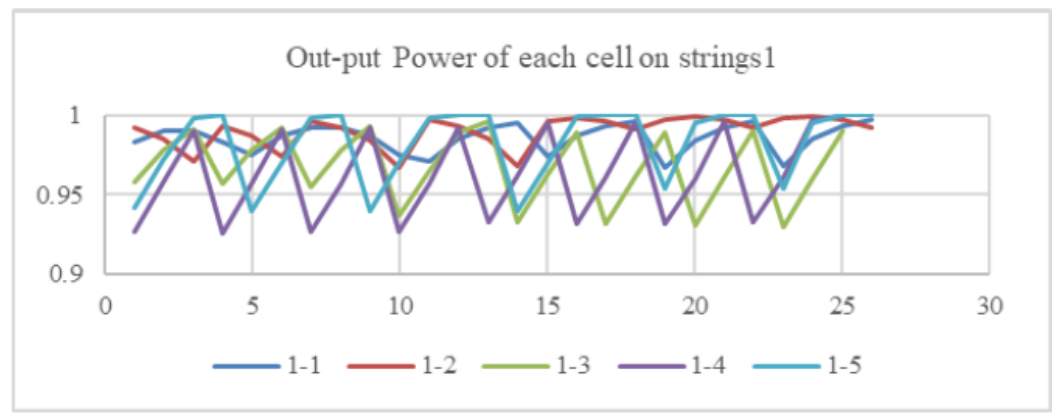

Figure 26: Module out-put power and each cell output power of String 1.

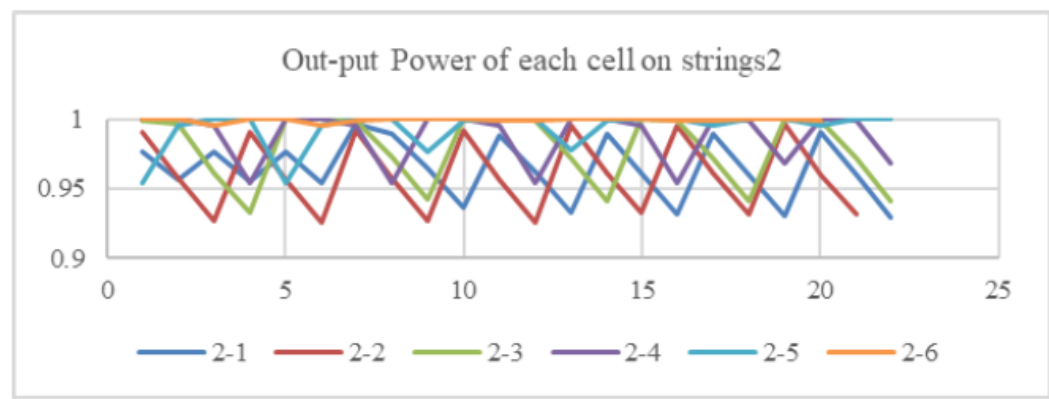

Figure 27: Module output power and each cell output power of String 2.

capacity of the solar cell, and the power generated by the solar cell cannot be collected unless the impedance matching of the output of each cell. "Bypass diode effect shown in Figure 17." Which considers the presence or absence of a bypass diode, is a simulation in which the power generated by a solar cell is collected in an impedance-matched state. Actually, impedance matching is achieved by MPPT, so it is necessary to consider each module to which MPPT is connected. We should expect a drop of at least $7 \%$ (module, 2-4) for string 1 and a drop of at least $6 \%$ (module, 2-3) for string 2. Impedance matching is performed by inserting an MPPT unit for each solar cell, and the power generated by each solar cell can be collected to the maximum.
We should expect a drop of at least $7 \%$ (module, 24) for string 1 and a drop of at least $6 \%$ (module, 2-3) for string 2. Impedance matching is performed by inserting an MPPT unit for each solar cell, and the power generated by each solar cell can be collected to the maximum. On the other hand, a control power supply is necessary; 10mAaround with SPV-1020.The power loss will be about 200mW (at @ 18V). And the power device loss is estimated to be $2.5 \mathrm{~W}$ (or more) with the conduction loss of the MOSFET resistance of $70 \mathrm{~m} \Omega\left(@ 25{ }^{\circ} \mathrm{C}\right)$ at the solar cell output of 6 A (Sun Power E60). Even if the switching loss in the boost converter operation is ignored, the power loss associated with the MPPT operation is $2.7 \mathrm{~W}$ or more. In the case of Horizon Ace, it has 267 solar cells, and 
the total output power is about $720 \mathrm{~W}$. With the current MPPT performance, it is not preferable to install MPPT for each cell. In the near future, if a device capable of high-speed switching (low switching loss) with an RdsON resistance of about $1.0 \mathrm{~m} \Omega$ appears and the loss of the MPPT control device is reduced to about 10$20 \mathrm{~mW}$, the MPPT will be installed in each solar cell [30, 31].

\subsection{Motor and Inverter Advancement}

Motors applicable to solar cars are classified and shown in Figure 28. DC motor from Bosch was used for Quiet Achiever; Solar Trek. It was $1 \mathrm{HP}$ with $24 \mathrm{~V}$ operating voltage. Since the DC motor can be easily driven by connecting the battery, it was often used for early solar cars. However, since the DC motor has a brush, it has inferior durability, low efficiency, large and heavy. Due to advances in power semiconductors, it has been replaced by DC BLM or AC motor [32]. It is noteworthy that AISIN Seiki participates in the WSC1996 with the SR motor and plays third prize. The motor type of each team is shown in Figure 29.

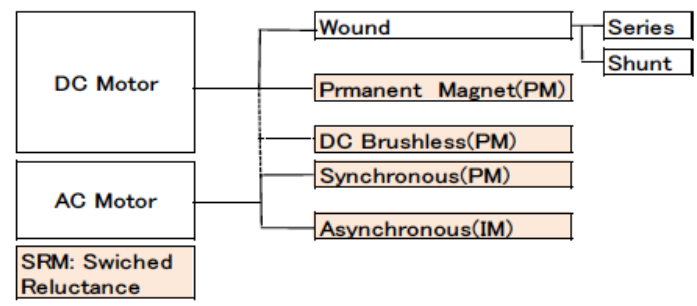

Figure 28: Motor types and classification.

PM DC BLM; Permanent Magnet DC brushless motor and $A C$ synchronous motor differ in name, but the magnetic structure of the motor is exactly the same. PM DCBLM has a rectangular drive waveform with rough position sensor such as Hall Effect sensor [33]. And AC synchronous motor has sinusoidal magnetization and driving waveform is sinusoidal with precise position sensor such as resolver. Figure $\mathbf{3 0}$ is the drive waveform of $D C B L M$ and $A C$ synchronous motor. Unique Mobility; UQM had developed DCBLM for GM Sunraycer and since it was marketed around at 1990, it had been adopted by many teams until 1999

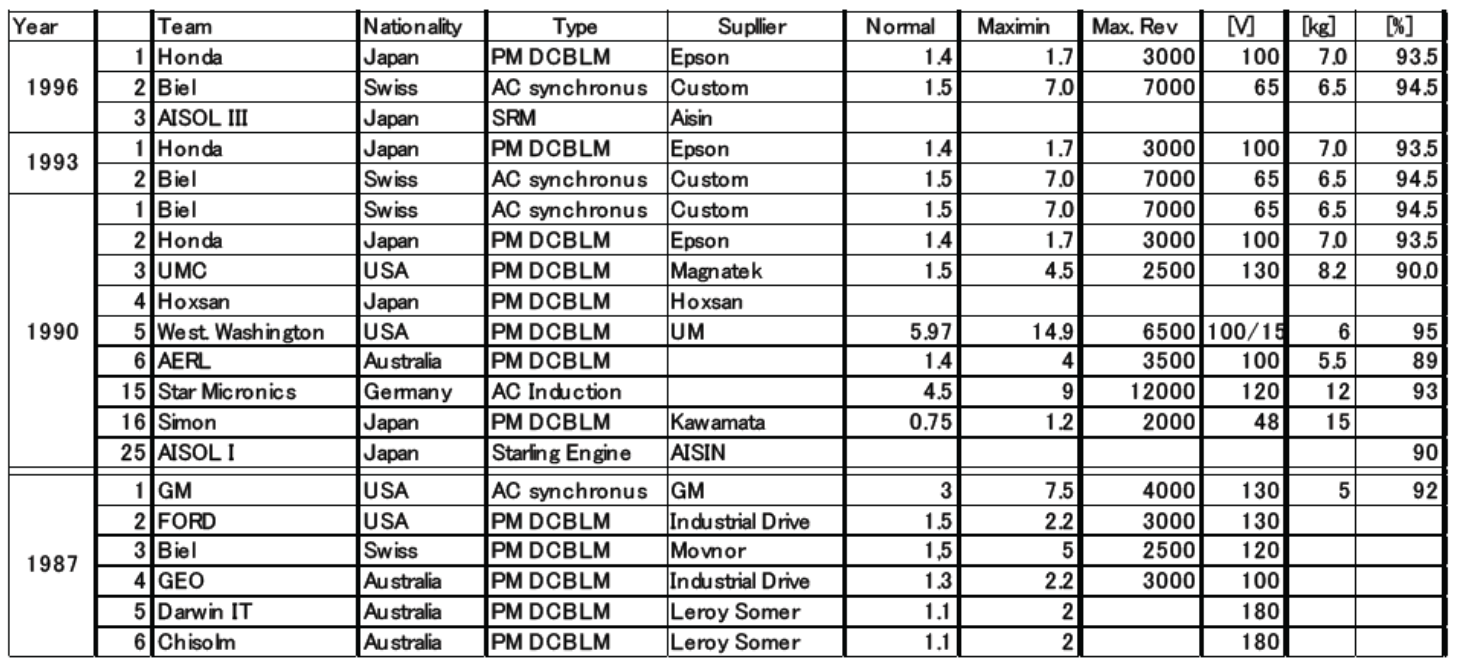

Figure 29: Motor type and results in 1990 around.

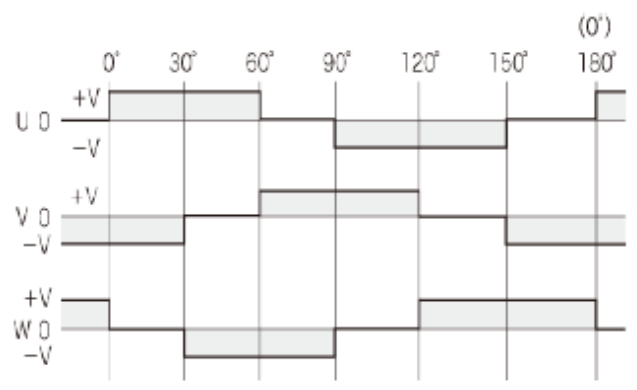

(a) DC BLM

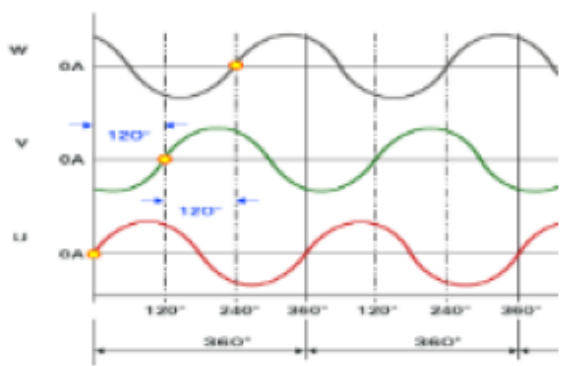

(b) AC synchronous.

Figure 30: Motor drive waveform: DC BLM and AC synchronous motor. 


\begin{tabular}{|l|l|r|r|}
\cline { 2 - 4 } Motor Spec. DR086 & CR10 & CR20 \\
\hline Rated Power & $\mathrm{kW}$ & 3.5 & 3.5 \\
\hline Peak Torqe (Cont.) & $\mathrm{Nm}$ & 6.8 & 6.8 \\
\hline Peak Torqe (Int.) & $\mathrm{Nm}$ & 18.1 & 13.6 \\
\hline Max. speed & $\mathrm{mm}$ & 5500 & 10000 \\
\hline Back EMF & $\mathrm{V} / \mathrm{Krpm}$ & 18.2 & 18.2 \\
\hline Torque constant & $\mathrm{Nm} / \mathrm{A}$ & 0.165 & 0.165 \\
\hline Max. winding temp. & deg. C & 150 & 150 \\
\hline Winding Resistance & ohms & 0.094 & 0.094 \\
\hline Winding Inductance & uH & 25 & 25 \\
\hline No. of poles & & 16 & 16 \\
\hline Rotor inertia & Nm*sec & 0.004 & 0.004 \\
\hline Motor wight & $\mathrm{kgf}$ & 4 & 4 \\
\hline Cooling & \multicolumn{2}{|c|}{ Forced Air } & \\
\hline
\end{tabular}

Figure 31: Motor spec.

[34]. The motor with inverter spec. is shown Figure 31. Figure 32 is the appearance of DR086S and CR10.Following UQM, Seiko Epson and Toshiba also developed solar car motors. Seiko Epson developed DCBLM for Honda Dream and they got first prize in WSC1993. Later this motor was supplied to Golden Eagle of KIT; Kanazawa Institute of Technology.

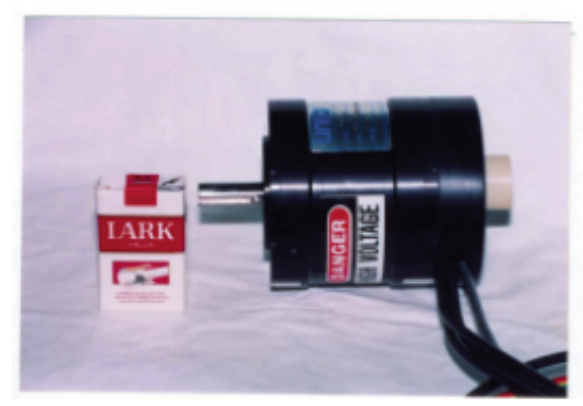

(a) Motor: DR086S.
Toshiba developed DCBLM and supplied to Kansai Electric Esperanza in 1992 and Skyace I (Ashiya University) in 1993. Toshiba Motor \& Inverter [35] are shown in Figure 33, and Figure $\mathbf{3 4}$ is its specification. They are implemented to Esperanza (See Figure 35) and Skyace III; so called TIGA in Malay, and while using the chain drive system with Toshiba DCBLM for the time being, it won the victory in 2000 and 2002(See Figure 36), second place in 2001 at Suzuka Dream cup.

\subsubsection{Development of In-Wheel Motor}

CSIRO developed new concept direct drive motor; In-Wheel motor [36] for Aurora in WSC1999 shown in Figure 37. The motor was required to fit inside a wheel to reduce aerodynamic drag, and to have maximum efficiency. The motor spec. Is shown in Figure 38. And they used "Halbach magnet array" in order to get best performance; $10 \mathrm{~W}(20 \%)$ loss decrease; shown in Figure 39. Figure $\mathbf{4 0}$ is the Aurora team solar car. This

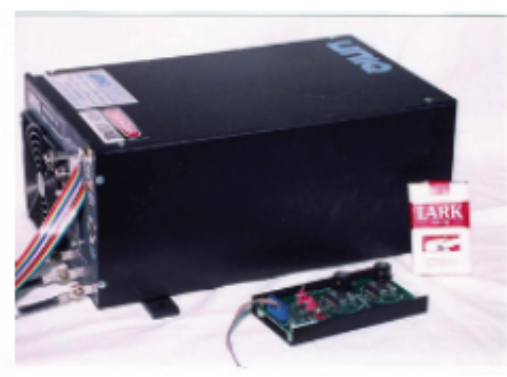

(b) Controller: CR10.

Figure 32: Appearance of Motor and Inverter.

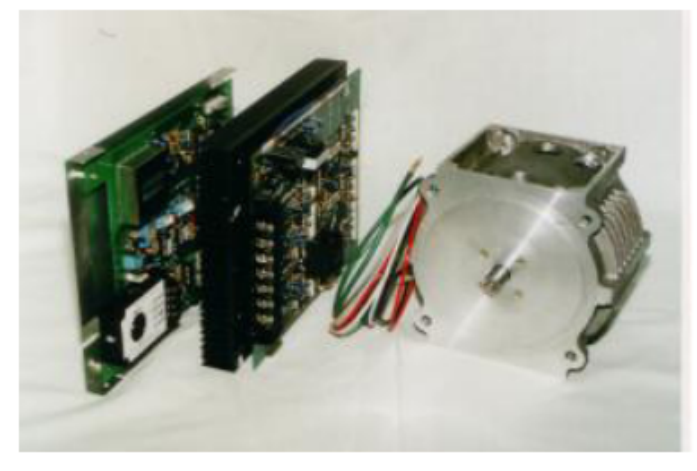

Figure 33: Motor \&Inverterby Toshiba.

\begin{tabular}{|l|c|r|}
\hline Out Dia. & $\mathrm{mm}$ & 158 \\
\hline Length & $\mathrm{mm}$ & 155 \\
\hline Weight & $\mathrm{kgf}$ & 8 \\
\hline Rot Oot Dia. & $\mathrm{mm}$ & 65.5 \\
\hline Rot Length & $\mathrm{mm}$ & 50 \\
\hline Core In Dia. & $\mathrm{mm}$ & 67.5 \\
\hline Core Length & $\mathrm{mm}$ & 45 \\
\hline Phase & & 3 \\
\hline poles & & 4 \\
\hline slots & & 27 \\
\hline Core Material & & $\mathrm{S} 9 \mathrm{t} 0.35$ \\
\hline Rated Voltage & $\mathrm{V}$ & 160 \\
\hline Max. speed & $\mathrm{rpm}$ & 5700 \\
\hline No Load current & $\mathrm{A}$ & 0.6 \\
\hline Rated Torque & $\mathrm{Nm}$ & 7.0 \\
\hline Rated current & $\mathrm{A}$ & 28 \\
\hline Max Eff. & \% & 94 \\
\hline
\end{tabular}

Figure 34: Toshiba DCBLM spec. 


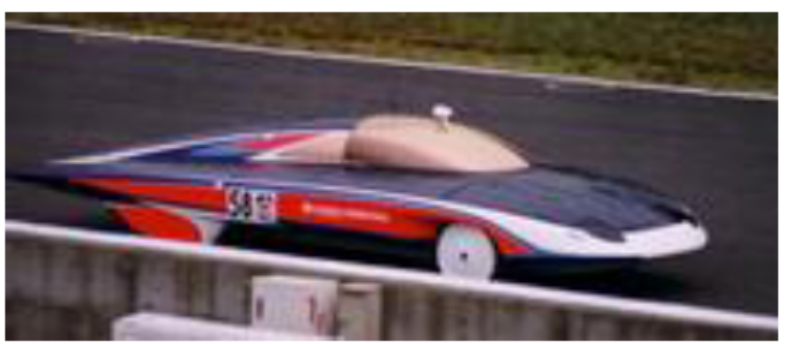

Figure 35: Esperanza I by KEPCO.

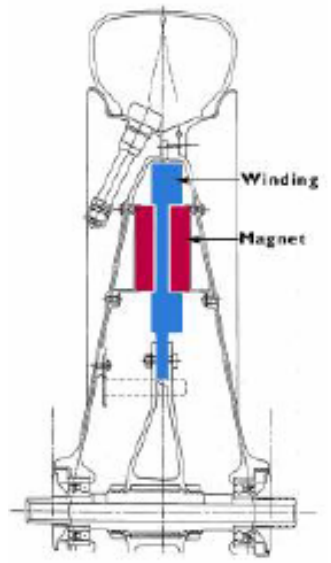

Figure 37: Motor sectional view of solarcar [11].

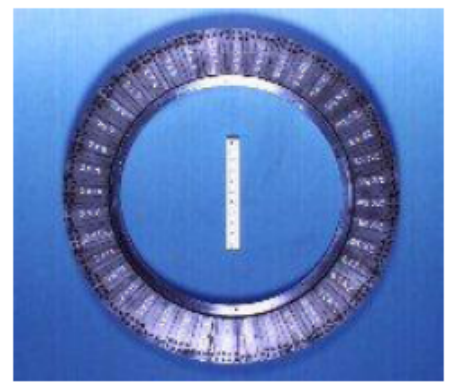

Figure 39: Halbach magnet array.

motor is supplied to Nuon and Michigan team later, but Halbach magnet array was not implemented [37].

Mitsubahas developed its own In-wheel motor with easy handling (install ability), and began to supply Japanese team from 2003. Figure 41 is the picture of Mitsuba In-wheel motor. TIGA and OSU used it at Phaeton 2004 (Athens Olympic pre-event) [38]. Circuit race and rally competition were the two events, TIGA won both [39]. Figure 42 is the comparison of chain drive and direct drive. In-wheel drive, although the transmission loss is very small, but the motor rotation speed corresponds to the vehicle speed, the re-duction ratio is fixed. On the other hand, since the chain drive can easily adjust the speed reduction ratio by replacing the sprocket, there is a feature that makes it possible to travel more efficiently against weather condition or

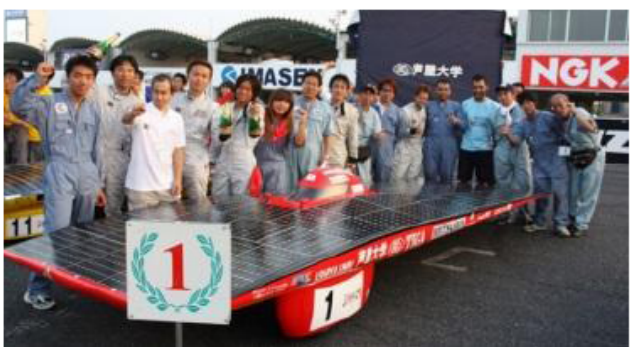

Figure 36: Skyace III: TIGA in Suzuka.

\begin{tabular}{|l|l|}
\hline Continuous output power & $1800 \mathrm{~W}$ \\
\hline Peak power for $72 \mathrm{~s}$ (hill climb) & $3.1 \times 1800 \mathrm{~W}$ \\
\hline Mean speed at $100 \mathrm{~km} / \mathrm{h}$ & $1060 \mathrm{rev} / \mathrm{min}$ \\
\hline Max. speed at $130 \mathrm{~km} / \mathrm{h}$ & $1380 \mathrm{rev} / \mathrm{min}$ \\
\hline Continuous torque & $16.2 \mathrm{Nm}$ \\
\hline Peak torque (hill climb) & $50.2 \mathrm{Nm}$ \\
\hline Starting torque & $50.2 \mathrm{Nm}$ \\
\hline Maximum outside diameter & $360 \mathrm{~mm}$ \\
\hline Maximum axial length & $43 \mathrm{~mm}$ \\
\hline Maximum active mass & $5 \mathrm{~kg}$ \\
\hline Mass penalty & $0.75 \mathrm{~W} / \mathrm{kg}$ \\
\hline
\end{tabular}

Figure 38: CSIRO In-Wheel motor spec [23].

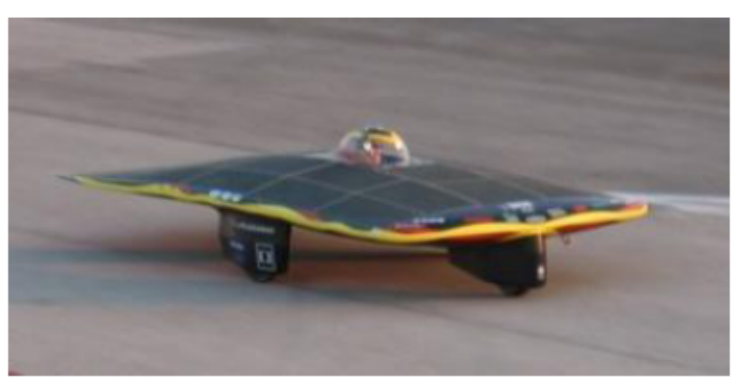

Figure 40: Aurora solar car [11].

uphill/downhill and the like, but transmission loss occurs. The Ashiya team actually exchanged speed reduction ratios between Alice Springs and Adelaide on climbing between Darwin - Alice Spring and descending in the race of WSC2001.

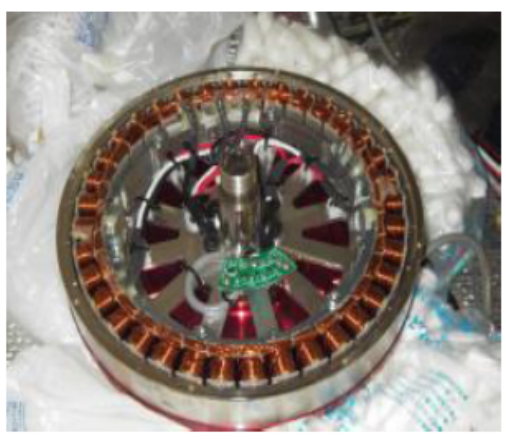

Figure 41: In-wheel motor by Mitsuba. 


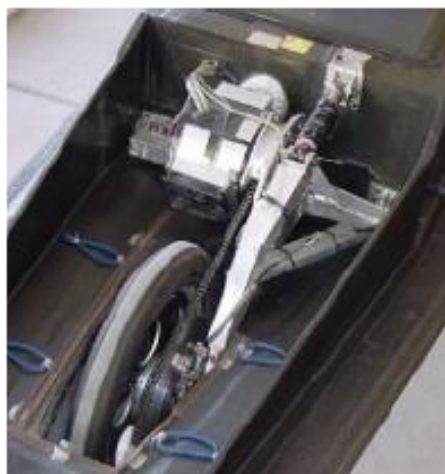

(a) Chain drive.

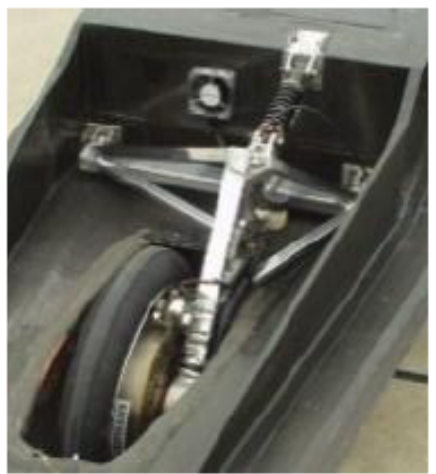

(b) In-wheel motor

Figure 42: Drive system advancement.

These two conflicting functions may be solved with "magnetic field weakening technique". Mitsuba mechanical method is realized by adjusting the opposing area with the magnet on the rotor surface and stator core which is moved in axial direction by additional actuator. Figure $\mathbf{4 3}$ is Mitsuba mechanical field weakening motor.

Meanwhile electrical control method has been widely used with $\mathrm{AC}$ synchronous motor control by current phase control. These techniques are useful especially for uphill / downhill circuit race in order to improve the drive and regenerative efficiency [40]. Mechanical one should have higher efficiency for up and down course and stop / go racing [41]. This technology might lead AshiyaSkyAce TIGA to win at "Solar car race in Suzuka" for many years [42].
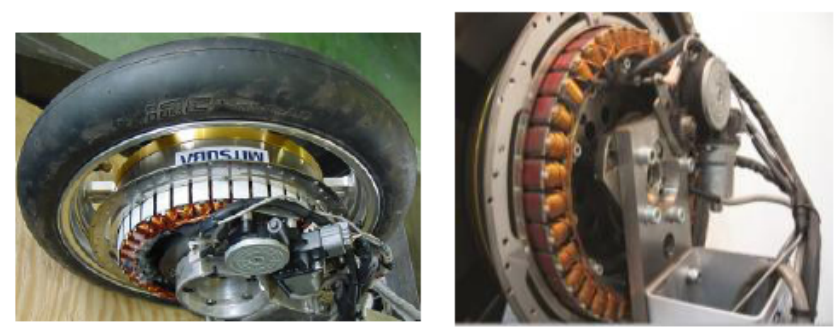

Figure 43: Mitsuba mechanically field weakening motor.

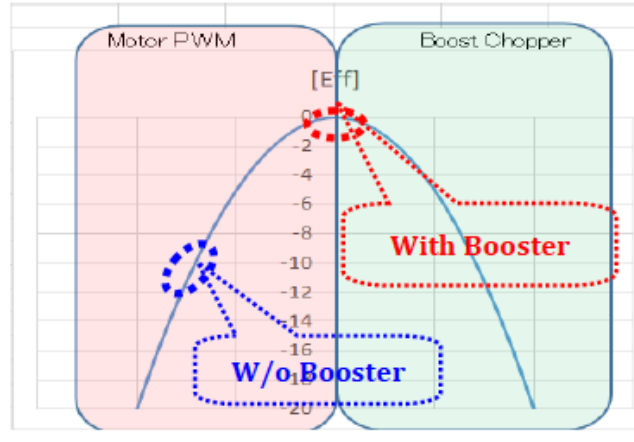

Figure 44: Mechanism of Booster loss improvement.

\subsubsection{Development of Voltage Booster}

In BWSC, the drive torque of the motor differs depending on the rise to an altitude of $1500 \mathrm{~m}$ from Darwin to Alice Springs and the descent to Adelaide, and the high-efficiency operating range of the motor changes. Using magnetic weakening control technology, the maximum efficiency point of the motor is adapted to the vehicle operating conditions. We have adopted a voltage booster in the BWSC17 to improve motor (and inverter) loss. Figure $\mathbf{4 4}$ shows the efficiency improvement mechanism. The output of the motor is adjusted by changing the applied voltage [43]. If there is no booster circuit, for example, the system will be designed to about 100km / h (@ 100V) at full accelerator. To cruise at $80 \mathrm{~km} / \mathrm{h}$, the PWM command will be around $80 \%$. As the duty of PWM becomes smaller, both motor loss and inverter loss increase, and the efficiency drops sharply.In a drive system equipped with a booster, the motor PWM command becomes $100 \%$ when cruising at $80 \mathrm{~km} / \mathrm{h}$ (@ 100V). When overtaking, the booster circuit is operated to raise the motor drive voltage to $120 \mathrm{~V}$ around. Figure $\mathbf{4 5}$ shows a booster circuit using a $\mathrm{GaN}$ power device. The effectiveness of the power booster circuit in $\mathrm{EV}$ drive was demonstrated by Toshiba in 1995 [44]. Since then, it has been adopted by the Toyota Prius in all models

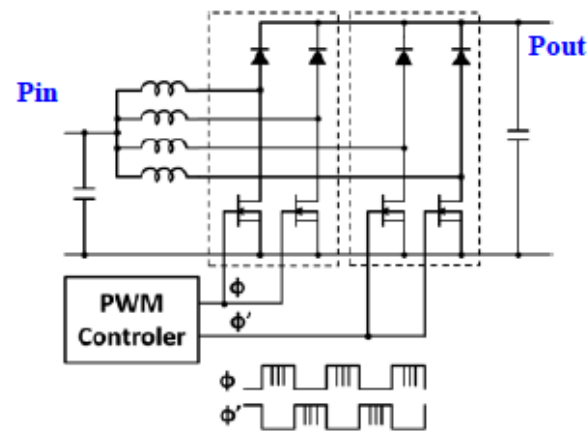

Figure 45: Booster circuit. 


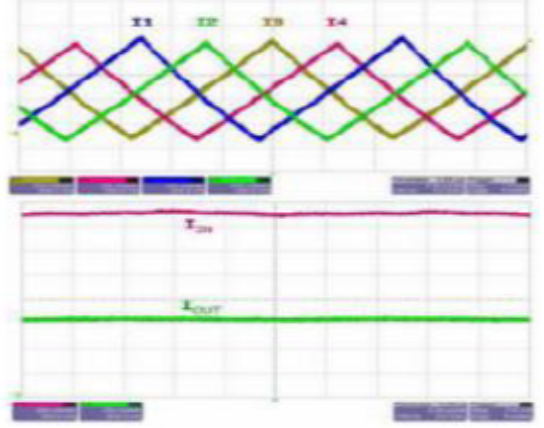

Figure 46: Reactor Current.

since the 2003 model. It is no exaggeration to say that booster motor systems are "Toshiba is the creator" and "Toyota is the parent".

What is important is that the operating efficiency of the motor can always be maintained high with respect to the wide dynamic range of the vehicle driving conditions. In particular, BWSC2017 uses a GaN power device with a small $\mathrm{ON}$ resistance when conducting, achieving high efficiency as an inverter (hardware) [45]. Figure $\mathbf{4 6}$ shows the current waveform in the reactor during boosting operation. And Figure 47 shows the efficiency and output power of the booster circuit.

If the boost rate is just about 1.1, the efficiency $99 \%$ (@ 1kW output) is obtained. Figure 48 shows the difference in running energy between without booster circuit (WSC2015) and with booster circuit (wsc2017). It has been shown that the booster circuit is expected to improve the loss of $8 \mathrm{kWh}(7906.6 \mathrm{Wh})$ when traveling from Darwin to Adelaide.

\begin{tabular}{|c|c|c|c|c|c|c|}
\hline Vehicle speed[km/h] & 80 & Acc. & 109 & 80 & Acc. & 100 \\
\hline solar power[w] & 960 & & & 960 & & \\
\hline \begin{tabular}{|l|} 
Power Drawn \\
from battery $[w]$
\end{tabular} & 49.6 & & & 109 & & \\
\hline Battery Voltage[V] & 95 & 95 & 95 & 120 & 120 & 120 \\
\hline Motor speed[rm] & 800 & - & 1200 & 800 & - & 1200 \\
\hline Mbcommand [\%] & 0 & 25 & 25 & - & - & - \\
\hline @Motor Voltage [V] & 95 & & 130 & 80 & & 120 \\
\hline @MotorTorque [Nm] & 10 & & & 10 & & \\
\hline Motor PWM[\%] & 100 & & 100 & 75 & & 100 \\
\hline MPPT Eff.[\%] & 99 & 99 & 99 & 99 & 99 & 99 \\
\hline Motor\&Inv. Eff.[\%] & 96 & 85 & 90 & 90 & 96 & 96 \\
\hline M.B. Eff.[\%] & 100 & 95 & 98 & 100 & 100 & 100 \\
\hline Driving period[Hours] & 37.5 & 0.5 & 2 & 37.5 & 0.5 & 2 \\
\hline System loss [Wh] & 6696 & 361 & 849.6 & 14715 & 89.3 & 357.1 \\
\hline Total loss[kWh] & & 906.6 & & & 5161.4 & \\
\hline Improvement[kWh] & 254. & & & & & \\
\hline
\end{tabular}

PWM loss difference of Motor\& Inv. at cruising speed.

Figure 48: Difference of booster equipped or not.

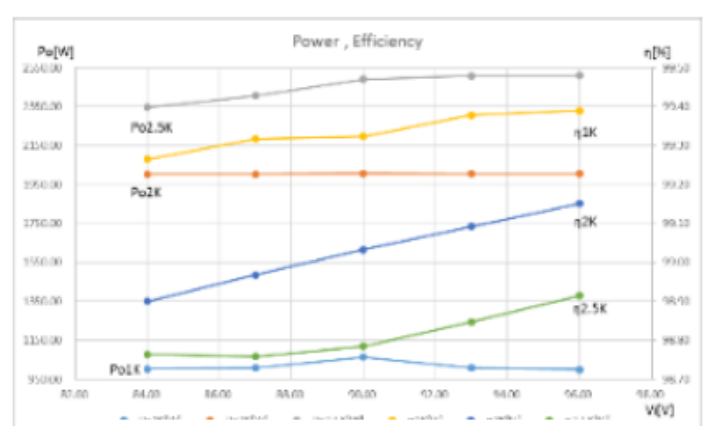

Figure 47: Booster efficiency.

Figure 49 is the photo of booster circuit installed in Horizon17. And we got the technical award from BWSC17.

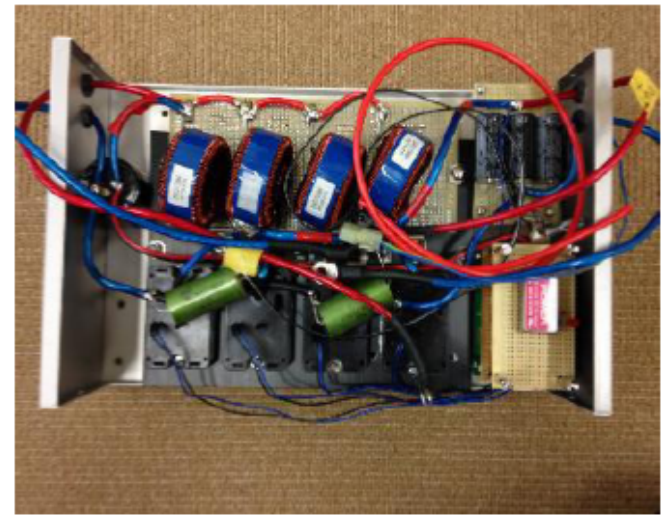

Figure 49: Booster circuit installed in Horizon 17.

\subsection{Magnet Evolution and Motor Performance Improvement}

The evolution of the motor is great due to progress of the magnet. Figure $\mathbf{5 0}$ shows the evolution of magnets. In the 1970s, advances in ferrite magnets led to the practical application of BLM for portable audio equipment and video equipment, and it spread to information devices such as FDDs and VCRs. Furthermore, ferrite magnets have evolved, and in the 1980 s, application to power motors such as fan motors and compressors for air conditioners began. Later, SmCo magnets and neodymium; $\mathrm{Nd}$ magnets appeared as new magnets [46]. Neodymium magnets have been used in HDD spindle motors and have become widespread. In 1986, GM developed a manufacturing process for $\mathrm{Nd}$ magnets, paving the way for power motor applications. It was WSC1987 that led to the victory when GM Sunraycer adopted the Nd coupling magnet motor. After that, Sumitomo Materials developed an $\mathrm{Nd}$ sintered magnet, and "Unique Mobility" incorporated it into a solar car drive motor 


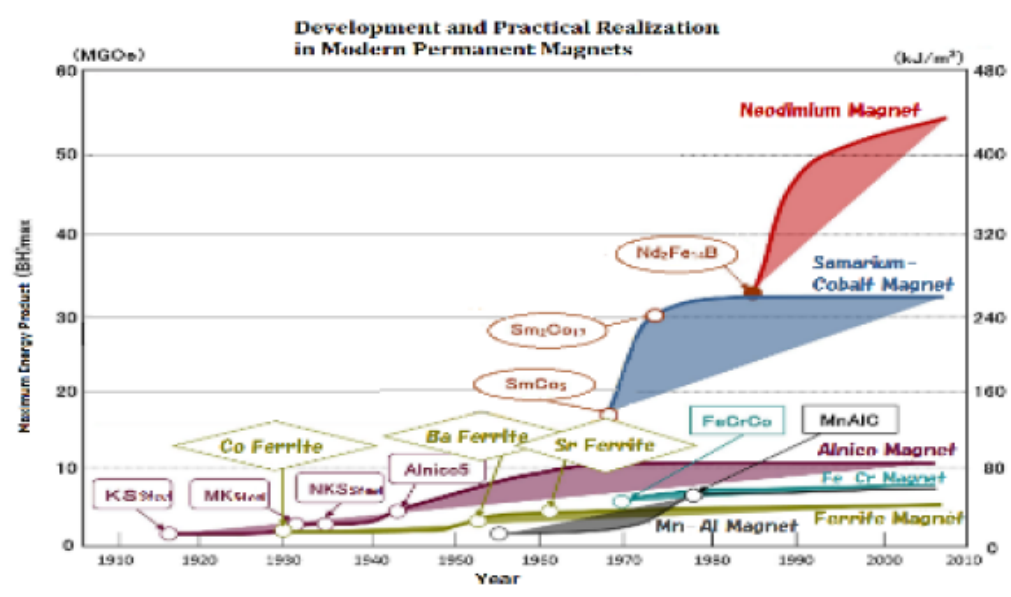

Figure 50: Magnet evolution.

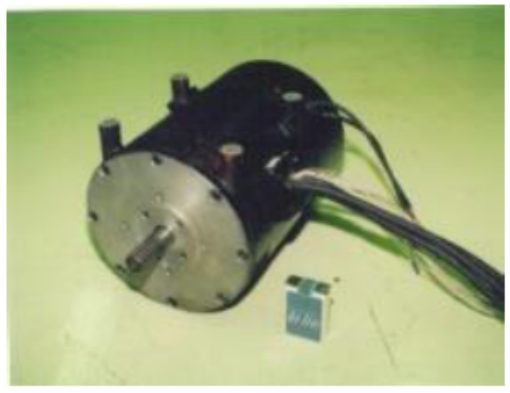

(a) EV drive motor with $\mathrm{Nd}$ magnet.

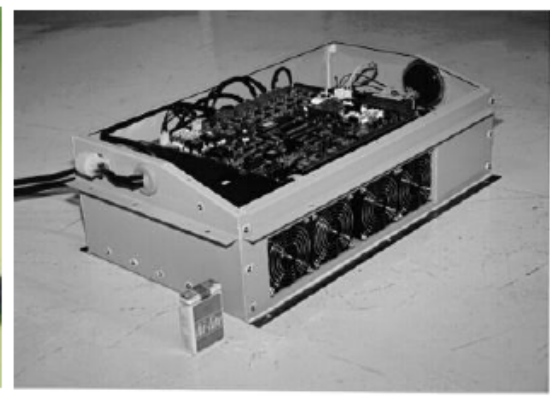

(b) Motor controller with booster circuit

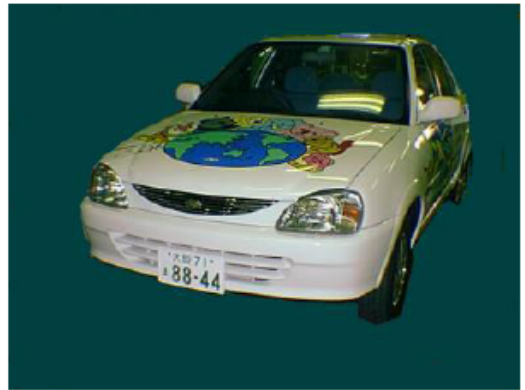

(c) Daihatsu Charade EV by KEPCO

Figure 51: EV drive system; motor \& controller and Daihatsu Charade EV.

(DR086) and commercialized it. It was adopted by many solar car teams in the early 1990 s.

After that, interestingly, the performance of $\mathrm{Nd}$ magnet power motor had been verified with solar car firstly, and it seems that it evolved into a motor for EV/HEV. In 1997 Toshiba developed an EV drive DCBLM using an $\mathrm{Nd}$ motor together with a controller shown in Figure 51. It had a boost converter to reduce motor loss. It was demonstrated at the 1997 Tokyo motor show. And we can say that these technologies had evolved into EV/HEV motor such as Prius or Leaf.

\subsection{Battery Advancement}

Solar cars are a kind of electric vehicles and battery performance greatly affects running performance [47]. Back to the WSC1987, three kinds of batteries were used. 17 teams adoptlead / acid batteries, 14 teams adopt silver / zinc batteries and 4 teams adopt nickel / zinc [48]. And the team de-signed by Australian John Barclay had no batteries at all, and it ranked 27 th. The top winning team used a solver / zinc battery. Of the top 15, 12 teams were silver / zinc, 2 team lead / acid, and 1 team was nickel / Zinc. The Silver / zinc battery was much higher than other types of batteries. SkyAceTIGA initially used lead / acid. After that, when I participated in WSC in 1993, I installed a higher performance nickel-zinc battery. As a result, despite the same capacity, the $90 \mathrm{kgf}$ battery mass is $40 \mathrm{kgf}$, which is a significant improvement in performance. However, nickel-zinc batteries were unlikely to extend their lifespan and were discontinued in 2001. It became necessary to introduce new batteries after 2002. A bench mark of battery is shown in Table 2 . We saw the lithium-ion battery as promising, but there were concerns about safety, and as a result of various investigations, we started mass production in 2000 and decided to find and adopt a safer lithium polymer battery.

As mentioned above, lithium polymer batteries are highly safe because they use polymer electrolytes, and in addition to conventional iron cans and aluminum cans, laminated films can be used as battery containers. In addition, since it does not require complicated housing parts, it can be made even smaller than a lithium-ion battery. On the other hand, the mechanical strength of the container is low and it is easily scratched, so it is necessary to devise a battery 
storage box. The lithium polymer battery installed in Phaethon 2004 is made by Kokam (Korea) [49], and 10 cells are connected in parallel to form one module, and 45 modules are connected in series, for a total of 450 . The storage battery box has a double structure of mild steel, the outer box is made of aramid / divinyl cell sandwich panel, and the inner box is made of styrene board. Figure $\mathbf{5 2}$ shows Li polymer battery cells and modules. And Figure $\mathbf{5 3}$ shows the battery stack.

Table 2: Battery Bench Mark

\begin{tabular}{|c|c|c|c|}
\hline Item & Wh/kg & Wh/L & Memory \\
\hline \hline Lithume ion & $100-240$ & $250-670$ & No \\
\hline Lithumeplymer & $100-260$ & $250-730$ & No \\
\hline $\mathrm{Pb}$ & $30-40$ & $60-75$ & No \\
\hline $\mathrm{AgO} / \mathrm{Zn}$ & 130 & 500 & No \\
\hline $\mathrm{NiCd}$ & $40-60$ & $50-150$ & Yes \\
\hline $\mathrm{NiMH}$ & $60-120$ & $140-300$ & Yes \\
\hline $\mathrm{NiZn}$ & $60-120$ & 280 & Yes \\
\hline
\end{tabular}

Lithium batteries have been adopted as EV drive batteries from the viewpoint of battery cost. It is considered that this is due to the synergistic effect of the development of the technology (BMS: Battery Management System) that guarantees the safety of batteries by electronic control and the release of many control ICs. As a result, the number of teams adopting $\mathrm{Li}$ ion batteries is increasing in BWSC as well. We have also adopted Li-ion batteries since WSC 2015 because of advancement of BMS reliability [50]. Although regulations on battery safety are becoming stricter year by year, the system (IC) of control devices is becoming more and more popular, making it easier for students (universities) to handle. LTC6804 (manufactured by Linear Technology) is used for our BMS developed for WSC2017 [51]. The battery used was 18650 made by Panasonic. Figure $\mathbf{5 4}$ shows the BMS system, and Figure $\mathbf{5 5}$ and Figure $\mathbf{5 6}$ show the battery module and stack each. Now Tesla Motor company is adopting 18650 type Lithium Batteries for EV.

\subsection{Power Device Advancement}

Social implementation of power semiconductors have started with silicon commutators, and bipolar transistors, GTOs (gate turn-off thyristors), IGBTs, and power MOSFETs, but conduction loss and switching loss are approaching the limits of Si devices. Now new wideband gap semiconductors such as $\mathrm{SiC}$ and $\mathrm{GaN}$ have emerged with is starting to hit the market. Figure 57 [52] shows suitable power device and Power Conversion application. $\mathrm{SiC}$ is use for high power Inverter such as train traction drive, HEV/EV traction and PV conditioner. On the other hand, GaN is used small power converter such as smart phone battery

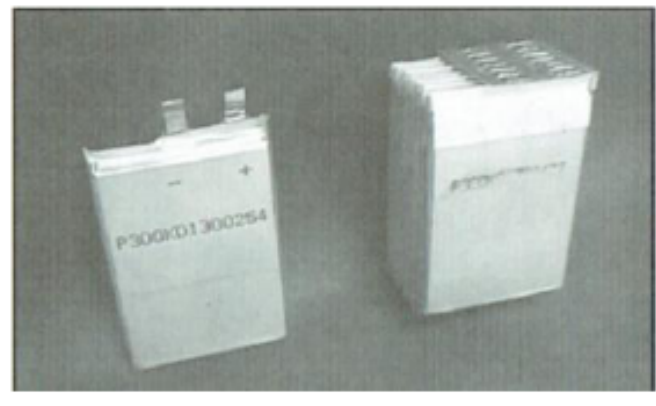

Figure 52: Lithium polymer battery cell and module.

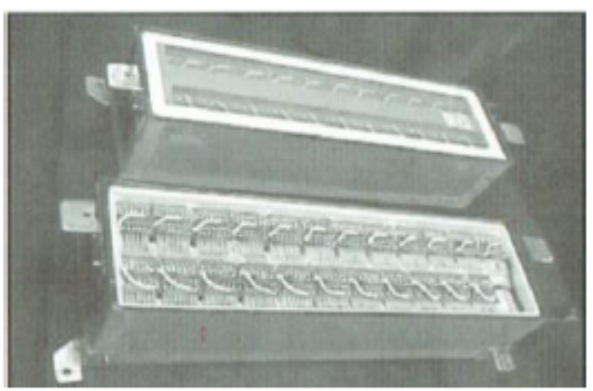

Figure 53: Lithium polymer battery stack. For SkyAce TIGA

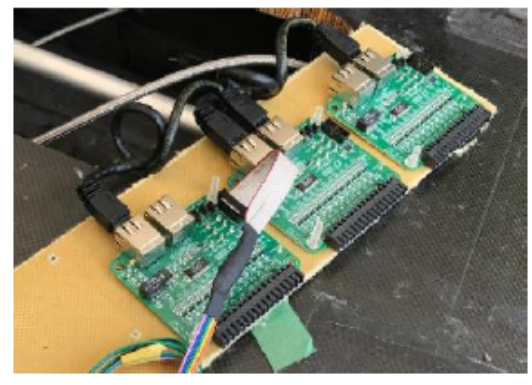

Figure 54: BMS for Horizon17.

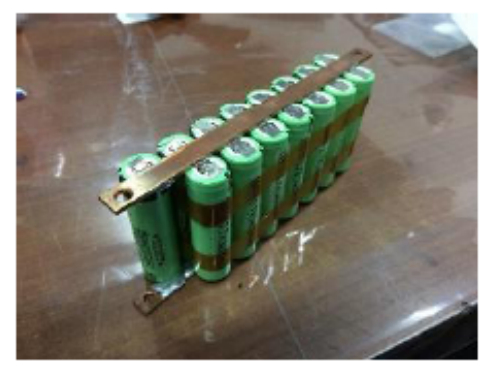

Figure 55: Battery module with 18650. Figure 56: Battery stack for Horizon 17.

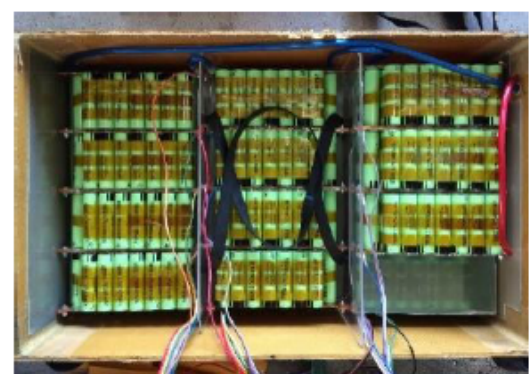


charger, PC ac-dc power supply. It is considered to be particularly suitable for small solar generators that are used standalone and are not connected to the grid. Then, it will be also suitable combination for small MPPTs for solar cars with low power consumption MPU/CPU/DSP [53].

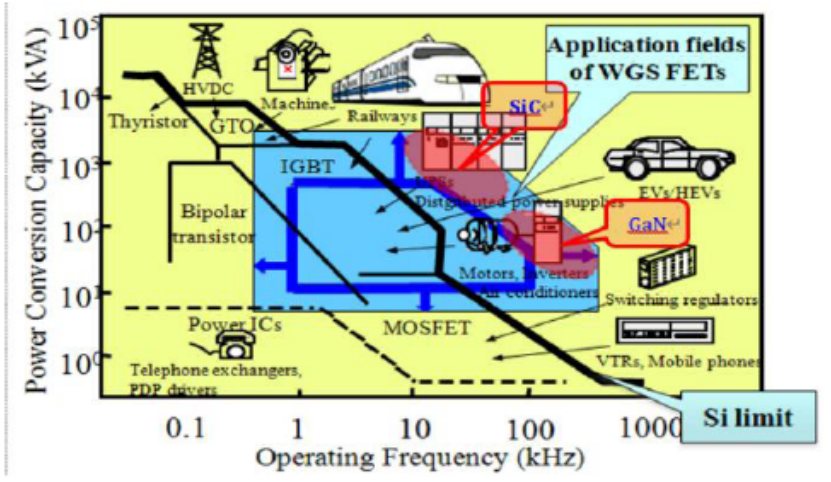

Figure 57: Power Conversion and Inverters, Power Devices.

\subsection{History of Solar Car System Development}

Figure 58 shows the transition of solar car drive technology, so-called power electronics, from the advent of semiconductors such as solar cells to the present. It can be seen that the new material technology was demonstrated in advance and implemented in society. On the other hand, advances in magnetic field analysis tools [54] and electrical system design simulation tools [55] for improving motor performance are also important. In the future, with the spread of new semiconductors such as GaN [56], power converters (inverters / converters) will become more compact [57]. In particular, polyphase and multiplexing will be promoted to reduce the size and loss of peripheral circuit equipment such as coils, transformers and capacitors.

\section{SUMMARY AND CONCLUSION}

Solarcar drive systems are a collection of power electronics technologies. In this paper, we have described the revolution of design concept for each component unit. It will be useful for the development of solar car electric system. In particular, regarding the impedance matching of solar cells connected in series, the MPPT unit of control needs to be finer, and it was shown that the combination with a GaN power device is the solution.

On the other hand, by developing a solar car, participating in the World Race (WSC), and new materials and technologies were demonstrated in the solar car and played a role in social implementation. Motor miniaturization, high efficiency, practical application of PWM inverter, development and practical application of the step-up MPPT, practical application of booster circuit motor drive system, in-vehicle application of multi-phase inverter / converter, etc. We believe that solar car racing (BWSC) has greatly contributed to the realization of an energy-saving society. We will continue to realize an energy-saving society by making full use of new magnetic materials, power devices such as $\mathrm{GaN} / \mathrm{SiC}$, and control technology.

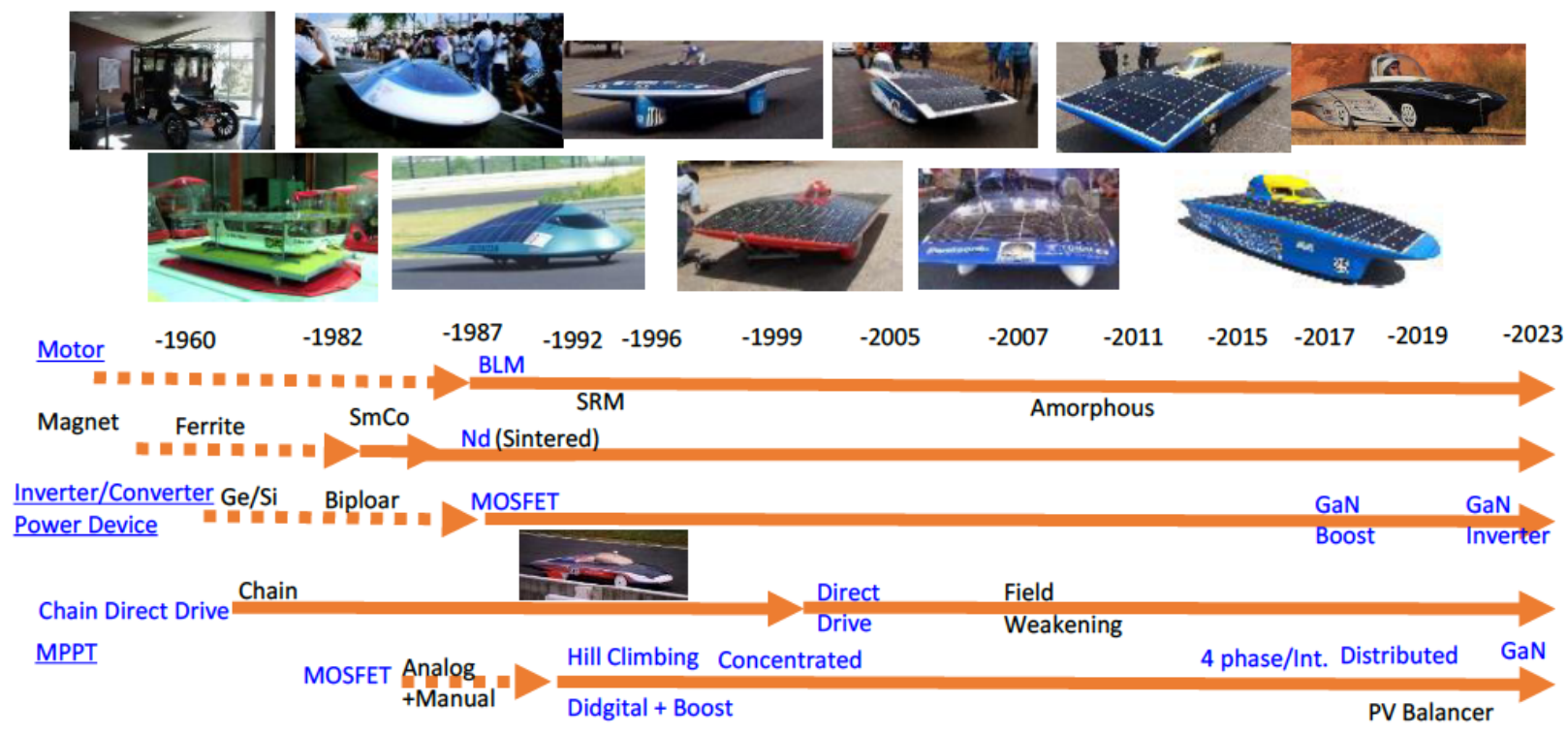

Figure 58: Transition of Solar car technology: Power Electronics. 


\section{REFERENCES}

[1] Hideki Jonokuchi et al., History of Solar Car and Its Electric Components Advancement and Its Future, (SDM-17) 26 to 28 April, 2017 at the University of Bologna, Bologna, Italy, Springer Publishing Company, Incorporated, ISBN:978-3319-57077-8.

[2] David M. Roche et al., Speed of Light: The 1996 World Solar Challenge, 1 Feb. 1998.

[3] Brandon Kretchmer et al., Solar Powered Electric Vehicle, Department of Mechanical and Civil Engineering College of Engineering and Sciences Purdue University Northwest April 26, 2017.

[4] DM. Chapin, CS. Fuller, and GL. Pearson, A New Silicon p-n Junction Photocell for Converting Solar Radiation into Electrical Power, Journal of Applied Physics 1954; 25: 676. http://sunlake.org/solar/archaeology/archaeology_j/japan3/ja pan_teams2.htm - aisin https://doi.org/10.1063/1.1721711

[5] Hideki Jonokuchi et al., Maximum output point control of solar cells, IEE-Japan Industry Applications Society Conference, No.135. 1992.

[6] Hideki Jonokuchi et al., High efficiency MPPT with boost Chopper, IEEJ conference, Oct. 1993, Sapporo Hokkaido.

[7] Hideki Jonokuchi et al., EV Drive System with Voltage Booster, Conf. Rec., EVS-13, Osaka, Japan 1996; 13-16: pp. 287-294.

[8] Takeshi Nishiuchi et al., Influence of Intergranular Grain Boundary Phases on Coercivity in Nd-Fe-B-based Magnets, Hitachi Metals Ltd. Engineering Journal, 2016; Vol. 32.

[9] Thomas R. Odhiambo et al., The Quest for New Solar Batteries, The New Scientist, 1960; 8(196): 18: 442-443.

[10] Georgia Hitch, World Solar Challenge: innovation has outstripped what event founder dreamed possible 30 years ago, ABC News, Posted Fri 6 Oct 2017 at 4:53am, https://www.abc.net.au/news/2017-10-06/world-solarchallenge-innovation-technology-outstrips-dreams/9019908.

[11] All about the Sensational Solar Car Race (WSC1987 Program).

[12] Racing with the sun. The 1990 world solar challenge. Chester R. Kyle. Society of Automotive Engineers, INC. ISBN 1-56091-1. P.52.

[13] Takahiro Iwata et al., Solar Battery Powered Vehicle 1993, Honda R \& D Technical Review, 1994; Vol.6.

[14] GM Sunraycer Case History/M-101, Society of Automotive Engineers; Reprint 1990/12/1, ISBN-10: 1560910135, ISBN13: $978-1560910138$

[15] Hughes News Quarterly International July-September, 1987; 15.

[16] Liu Chunhua et al., A permanent-magnet hybrid in-wheel motor drive for electric vehicles, Vehicle Power and Propulsion Conference, 2008. VPPC '08. IEEE. https://doi.org/10.1109/VPPC.2008.4677525

[17] Hideki Jonokuchi, Comparison of UNIQUE DC brushless motor and induction motor, IEE-Japan, 4 Feb. 1994.

[18] Masayoshi Umeno, Report of 7th International Photovoltaic Science and Engineering Conference in Nagoya @Nov. 1993, Organizer of 7th International Photovoltaic Science and Engineering Conference, Japan Society of Applied Physics and IEEJ. 1994.

[19] Minoru Kaneiwa et al., Space solar cells using III-V compound semiconductors, Sharp Technical Journal 2002; 83: 54-57.

[20] Douglas R Carroll, The Winning Solar Car : A Design Guide for Solar Race Car Teams (Paperback), SAE International, January, 2003.

https://doi.org/10.4271/R-343
[21] Takahiro Iwata et al., Honda Dream development, EVS9: The 9th Electric Vehicle Symposium (Toronto, Ontario, Canada).

[22] Takahiro Iwata et al., Solar battery-powered vehicle, Honda R \& D Technical Review, 1991; 3.

[23] Tomohiro Shimizu et al., Solar Car Driving Strategy System, Automotive Technology, 1995; 49(7).

[24] Takayuki Yoshida, Features of 8096 and application to DC servo motor control, Interface CQ Publishing Co. Ltd., 1998 14(1): 291-311.

[25] Masaaki Hatoh et al., Ashiya University Solar Car Development Research (3rd Report), Ashiya University report 2003; 38: 117-132.

[26] STMicro, Application note, 300 W PV converter to be integrated into a photovoltaic panel based on SPV1020 and bypass diodes SPV1001N30 and SPV1001N40, Doc ID 023149 Rev 1, April 2012.

[27] STMicro Application note, Designing with SPV1020 interleaved boost converter with MPPT algorithm, AN3392, 02 May 2011.

[28] STMicro, Data sheet, SPV1020; Interleaved DC-DC boost converter with built-in MPPT algorithm.

[29] Maxim Application note 6608, How to optimize performance when using synchronous rectification in nonisolated DC-DC converters, 06 Jun, 2018.

[30] Hideki Jonokuchi, Solar and wind power utilization technology in the eco-era: Solar power generation system and solar car for racing, Transistor technology, Vol. 47 No.3, p118-129.

[31] Hideki Jonokuchi et al., Basics and applications of solar cell utilization, CQ Publishing Co. Ltd. ISBN9784789841290.

[32] Masami Hirata et al., Comparison of motor operating efficiency between PM motor and IM, IEE-Japan, 27 July 1994.

[33] Shinichi Hashimoto et al., Development of high-efficiency drive system for EV, 1996 Achievement Issue Toshiba Review, March 1997.

[34] Jeff Brown, High Efficiency Permanent Magnet Motor, Marand Precision Engineering, 27 October 2010.

[35] Takayuki Yoshida, Features of 8096 and application to DC servo motor control, Interface CQ Publishing Co. Ltd., 1998; 14(1): 291-311.

[36] VS Ramsden et al., design of an in-wheel motor for a solarpowered electric vehicle, IEE Proceedings - Electric Power Applications 1998; 145(5): 402-408. https://doi.org/10.1049/ip-epa:19982167

[37] Oliver Winter et al., Ironless In-Wheel Hub Motor Design by Using Multi-Domain Finite Element Analyses, International Symposium on Power Electronics 2012. https://doi.org/10.1109/SPEEDAM.2012.6264394

[38] Hideki Jonokuchi etc., Analyzing the AshiyaSkyAce TIGA element technology, Machine design, The Nikkan Kogyo Shimbun, 2005; 49(1): ISSN-0387-1045.

[39] Hideki Jonokuchi etc., Analyzing the AshiyaSkyAce TIGA element technology, Vehicle weight reduction, The Nikkan Kogyo, Shimbun, 2005; 49(3): ISSN-0387-1045.

[40] Hideki Jonokuchi etc., Analyzing the AshiyaSkyAce TIGA element technology, Research on electrical / drive systems The Nikkan Kogyo, 2005; 49(4): ISSN-0387-1045, Shimbun.

[41] Masaaki Hatoh et al., GaAs solar cells and variable magnetic flux motors for racing solar car, Proceeding of Japan Solar Energy Society, Japan Wind Energy Association, 2006; p 3942.

[42] Kunio Nakagawa et al., Recent status of racing solar cars, Society of Automotive Engineers of Japan, Inc., Vol.63, No.9, p73-78. 
[43] Hideki Jonokuchi, Solar Powered Vehicle of NIT challenging WSC2017 in Australia, PV-SEC27, 2017; 12-17, Otsu Prince Hotel, Japan.

[44] Hideki Jonokuchi et al., EV Drive System with Voltage Booster, Conf. Rec., EVS-13, Osaka, Japan, October 1996; 13-16, pp. 287-294.

[45] Akio Nakagawa, Shinohe Takashi, Evolving Technologies for Discrete Semiconductor Devices, Toshiba Review, 2000; 55(1).

[46] Yasuhiro Marukawa et al., Motor Application of NEOMAX® Nd-Fe-B Anisotropic Ring Magnets, Hitachi Metals Engineering Journal, Vol. 35(2019).

[47] Nobuyuki Ishizawa, Actual conditions and future prospects of the in-vehicle and industrial storage battery market, Japan Economic Center Co., Ltd., 2015.

[48] AlyceMoncourtois, Sunraycer; Illuminating the Path toward the Modern Electric Vehicle, Aero Vironment Inc., 2021.

[49] YoshioUetani, Polymer Lithium Battery, CMC Publishing Co. Ltd., 1999.

[50] Tohru Moriya et al., About the electric system measuring instrument and measuring method of the solar car, Solar car prototype workshop, Japan Solar Energy Society, Jan. 2008.

[51] N Chasanah, D Anggraeni, A Wirawan, Analysis of battery charging in the development of BMS for solar UAV application, 6th International Seminar of Aerospace Science and Technology, 2018.

https://doi.org/10.1088/1742-6596/1130/1/012012

[52] Giorgia Longobardi, GaN for power devices: Benefits, applications, and normally-off technologies, 2017 International Semiconductor Conference (CAS), October 2017.

https://doi.org/10.1109/SMICND.2017.8101144

[53] Wei Hwang, New trends in low power SoC design technologies, SOC Conference 2006 IEEE International, 2006; pp. 211-214.

[54] Md. Rokonuzzaman et al., Design of a MPPT Solar Charge Controller in Matlab-Simulink GUI Environment, International Conference on Mechanical Engineering and Applied Science (ICMEAS)At: Mirpur Cantonment, Dhaka 2017; Volume: 1st.

[55] JMAG Catalog, JMAG: Motor model-based development example, (c) 2018-2020 JSOL Corp.

[56] Tetsuzo Ueda, GaN power devices: current status and future challenges, Japanese Journal of Applied Physics 2019; 58(SC): SC0804 https://doi.org/10.7567/1347-4065/ab12c9

[57] Sandor. Halasz, PWM strategies of multi-phase inverters Industrial Electronics, 2008. IECON 2008. 34th Annual Conference of IEEE, December 2008. https://doi.org/10.1109/IECON.2008.4758075

DOI: https://doi.org/10.31875/2410-2199.2021.08.8

(c) 2021 Hideki Jonokuchi; Zeal Press.

This is an open access article licensed under the terms of the Creative Commons Attribution Non-Commercial License (http://creativecommons.org/licenses/by-nc/3.0/), which permits unrestricted, non-commercial use, distribution and reproduction in any medium, provided the work is properly cited. 